Comparison of SARS-CoV-2 evolution in vitro during passage in Vero and primary human airway cells

\title{
Collaboration Between Host and Viral Factors Shape SARS-CoV-2 Evolution
}

Connor G. G. Bamford ${ }^{1 *}$, Lindsay Broadbent ${ }^{1}$, Elihu Aranday-Cortes ${ }^{2}$, Mary McCabe $^{1}$, James McKenna ${ }^{3}$, David Courtney ${ }^{1}$, Olivier Touzelet ${ }^{1}$, Ahlam Ali $^{1,4}$, Grace Roberts ${ }^{1}$, Guillermo Lopez Campos ${ }^{1}$, David Simpson ${ }^{1}$, Conall McCaughey ${ }^{3}$, Derek Fairley ${ }^{3}$, Ken Mills ${ }^{4}$, Ultan F. Power ${ }^{1 *}$, and the Breathing Together Investigators ${ }^{ \pm}$

${ }^{1}$ Wellcome-Wolfson Institute for Experimental Medicine, Queen's University Belfast, Belfast, UK.

2 Medical Research Council-University of Glasgow Centre for Virus Research, University of Glasgow, Glasgow, UK.

${ }^{3}$ Regional Virus Laboratory, Belfast Health and Social Care Trust, Belfast, UK

${ }^{4}$ Patrick. G. Johnston Centre for Cancer Research, Queen's University Belfast, Belfast, UK.

${ }^{*}$ co-corresponding authors

Connor G. G. Bamford email: c.bamford@qub.ac.uk

Ultan F. Power email: u.power@qub.ac.uk

$\pm=$ Breathing Together investigators: Professor Andrew Bush, Professor Adnan Custovic, Professor Peter Ghazal, Dr. Mindy Gore, Professor Jonathan Grigg, Professor Clare M. Lloyd, Professor Benjamin Marsland, Professor Ultan Power, Professor Graham Roberts, Professor Sejal Saglani, Professor Jurgen Schwarze, Professor Mike Shields, and Professor Steve Turner. 
Comparison of SARS-CoV-2 evolution in vitro during passage in Vero and primary human airway cells

SARS-CoV-2 continues to evolve, resulting in several 'variants of concern' with novel properties. The factors driving SARS-CoV-2 fitness and evolution in the human respiratory tract remain poorly defined. Here, we provide evidence that both viral and host factors co-operate to shape SARS-CoV-2 genotypic and phenotypic change. Through viral whole-genome sequencing, we explored the evolution of two clinical isolates of SARS-CoV-2 during passage in unmodified Vero-derived cell lines and in parallel, in well-differentiated primary nasal epithelial cell (WD-PNEC) cultures. We identify a consistent, rich genetic diversity arising in vitro, variants of which could rapidly rise to near-fixation with 2 passages. Within isolates, SARS-CoV-2 evolution was dependent on host cells, with Vero-derived cells facilitating more profound genetic changes. However, most mutations were not shared between strains. Furthermore, comparison of both Vero-grown isolates on WD-PNECs disclosed marked growth attenuation mapping to the loss of the polybasic cleavage site (PBCS) in Spike while the strain with mutations in NSP12 (T293I), Spike (P812R) and a truncation of ORF7a remained viable in WD-PNECs. Our work highlights the significant genetic plasticity of SARS-CoV-2 while uncovering an influential role for collaboration between viral and host cell factors in shaping viral evolution and fitness in human respiratory epithelium. 
Comparison of SARS-CoV-2 evolution in vitro during passage in Vero and primary human airway cells

\section{Introduction}

Severe acute respiratory syndrome coronavirus 2 (SARS-CoV-2) (Family: Coronaviridae; Genus: Betacoronavirus) has a positive-sense, non-segmented, single-stranded RNA genome of $\sim 30,000$ nucleotides in length (Lu et al., 2020; Wu et al., 2020). The SARS-CoV-2 genome encodes at least 29 proteins, expressed from translation of a $5^{\prime}$ major open reading frame (ORF1ab), including Nsp3 and Nsp12 (viral RNAdependent RNA polymerase), and a series of nested transcripts at the $3^{\prime}$ terminus, including Spike ( $S$; the viral attachment and fusion glycoprotein) and ORF7a. SARS-CoV-2 emerged into the human population in late 2019, causing coronavirus virus disease 2019 (COVID19) (Wang et al., 2020). Reflecting its likely zoonotic origins, SARSCoV-2-like and other SARS-related viruses have been detected and isolated from horseshoe bats and pangolins from Asia (Boni et al., 2020). SARS-CoV-2 is a highly transmissible virus with an R0 of up to $\sim 5$, and has a relatively high case mortality rate $(\sim 1 \%)$, especially pathogenic in elderly or individuals with co-morbidities (Cevik et al., 2020). While safe and effective vaccines were recently developed (Krammer, 2020), there is a dearth of highly-effective therapeutic interventions, with notable exceptions such as dexamethasone (Recovery Group, 2021).

SARS-CoV-2 productively infects the epithelial cells lining the upper and lower respiratory tract, including those in the nasal cavity and the alveoli of the lung (Hou et al., 2020). By virtue of interaction with Spike, SARS-CoV-2 exploits host cell protein angiotensin-converting enzyme 2 (ACE2) as its receptor (Shang et al., 2020). Additionally, for entry to occur Spike requires activation by two host proteases, furin and transmembrane protease serine 2 (TMPRSS2)-like proteases, which cleave Spike at the S1/S2 boundary between its two subunits (S1 and S2) and the S2' site in S2 allowing release of the fusion peptide (Hoffmann et al., 2020). Following binding to ACE2, a proteolytically-activated Spike 
Comparison of SARS-CoV-2 evolution in vitro during passage in Vero and primary human airway cells

can fuse the viral envelope with the host cell membrane releasing the infectious genome into the cytoplasm.

Since its initial emergence, SARS-CoV-2 has continued to evolve and adapt to the human population with several putatively beneficial mutations arising in Spike, such as D614G and N501Y, that affect Spike stability and binding to ACE2, and antibody-escape mutations in the amino-terminal domain (NTD) (Harvey et al., 2021). Additionally, loss of the polybasic cleavage site (PBCS), which is a unique feature of SARSCoV-2 and facilitates furin cleavage at the S1/S2 boundary, has been demonstrated to reduce transmission and virulence of SARS-CoV-2 in animal models (Johnson et al., 2021; Peacock et al., 2021). Together, these mutations of interest are found in constellations in so-called 'variants of concern' (VOC), which are strains of SARS-CoV-2 with evident phenotypic differences, such as enhanced transmissibility, pathogenicity, or reduced sensitivity to antibody-mediated neutralization in humans (Harvey et al., 2021).

As SARS-CoV-2 continues to spread, and interventions and vaccines are being rolled out, there remain significant unknowns as to how SARSCoV-2 may adapt further to humans. Knowledge of the genetic and molecular correlates of this difference in transmissibility is crucial for understanding of coronavirus pandemic preparedness and inform strategies for surveillance and control. In vitro models can help disentangle the factors affecting evolution, identify new ones, and highlight mutational tolerance. Here, we undertook a side-by-side comparison of SARS-CoV-2 evolution by whole genome sequencing of two isolates, grown in parallel in standard Vero-derived cells and human 'welldifferentiated primary nasal epithelial cells' (WD-PNECs), which are a useful model for probing virus-host interactions in the respiratory tract (Guo-Parke et al., 2013; Hou et al., 2020; Villenave et al., 2012). Our data demonstrate clear roles of both viral and host cell factors in 
Comparison of SARS-CoV-2 evolution in vitro during passage in Vero and primary human airway cells

shaping SARS-CoV-2 genetic and functional changes, identifying genetic features required for efficient infection of primary cells.

\section{Results}

Isolation and passage of SARS-CoV-2 in unmodified Vero-derived cells

To begin to understand the evolution of SARS-CoV-2 we first needed to generate characterised stocks of virus (Fig 1A). In the first instance, a low passage isolate (passage 1, P1) of SARS-CoV-2 (England 02/20) was obtained from Public Health England (PHE) and is referred to as 'PHE'. This stock was from a sample isolated on VeroE6 cells and represents one of the earliest isolates of SARS-CoV-2 in the UK during the pandemic. PHE is from clade $A$ and does not contain the D614G substitution in Spike (supplementary table 1)(Davidson et al., 2020; Holden et al., 2020). Upon receipt, we carried out a further three passages on VeroE6 cells passaging at an MOI of 0.001 , harvesting stocks at 96 hpi when extensive cytopathic effect was observed. The PHE strain grew efficiently, reaching titres of $>10^{6} \mathrm{pfu} / \mathrm{mL}$ (Fig 1B) and was cytopathic, inducing 'webbing' and cell rounding, consistent with previous reports (data not shown).

As we wanted to understand the viral factors that may drive evolution and results obtained from only one isolate may be nonrepresentative, we next obtained an independent - but comparable clinical nasal/pharyngeal swab sample containing SARS-CoV-2, which we termed BT20.1 (Belfast 06/20). This strain represents an isolate from the UK's 'first wave' and is a representative of clade $B$ that contains the D614G mutation in Spike (table 1). Unlike PHE, BT20.1 was isolated on standard Vero cells (CCL-81) and passaged to P4 (multiplicity of infection 
Comparison of SARS-CoV-2 evolution in vitro during passage in Vero and primary human airway cells

149 [MOI] 0.001 and passaged every 3 days). Like PHE, BT20.1 grew 150 efficiently, reaching titres of $>10^{6} \mathrm{pfu} / \mathrm{mL}$ (Fig 1B).

$151 \quad$ Both PHE and BT20.1 formed plaques on standard Vero cells in all 152 passages (Fig 1C and D). Comparison of plaque sizes between P2 and P4 153 identified differences in plaque size composition following Vero cell 154 passage. This was most evident for $\mathrm{PHE}$, which became predominantly 155 large plaques (Fig 1 E and F). As observed in the plaque edge, BT20.1 156 induced consistent cell-to-cell fusion, unlike PHE (sFig 1 A and B). 
bioRxiv preprint doi: https://doi.org/10.1101/2021.07.16.452629; this version posted July 16, 2021. The copyright holder for this preprint

(which was not certified by peer review) is the author/funder, who has granted bioRxiv a license to display the preprint in perpetuity. It is made available under aCC-BY-NC-ND 4.0 International license.

Comparison of SARS-CoV-2 evolution in vitro during passage in Vero and primary human airway cells
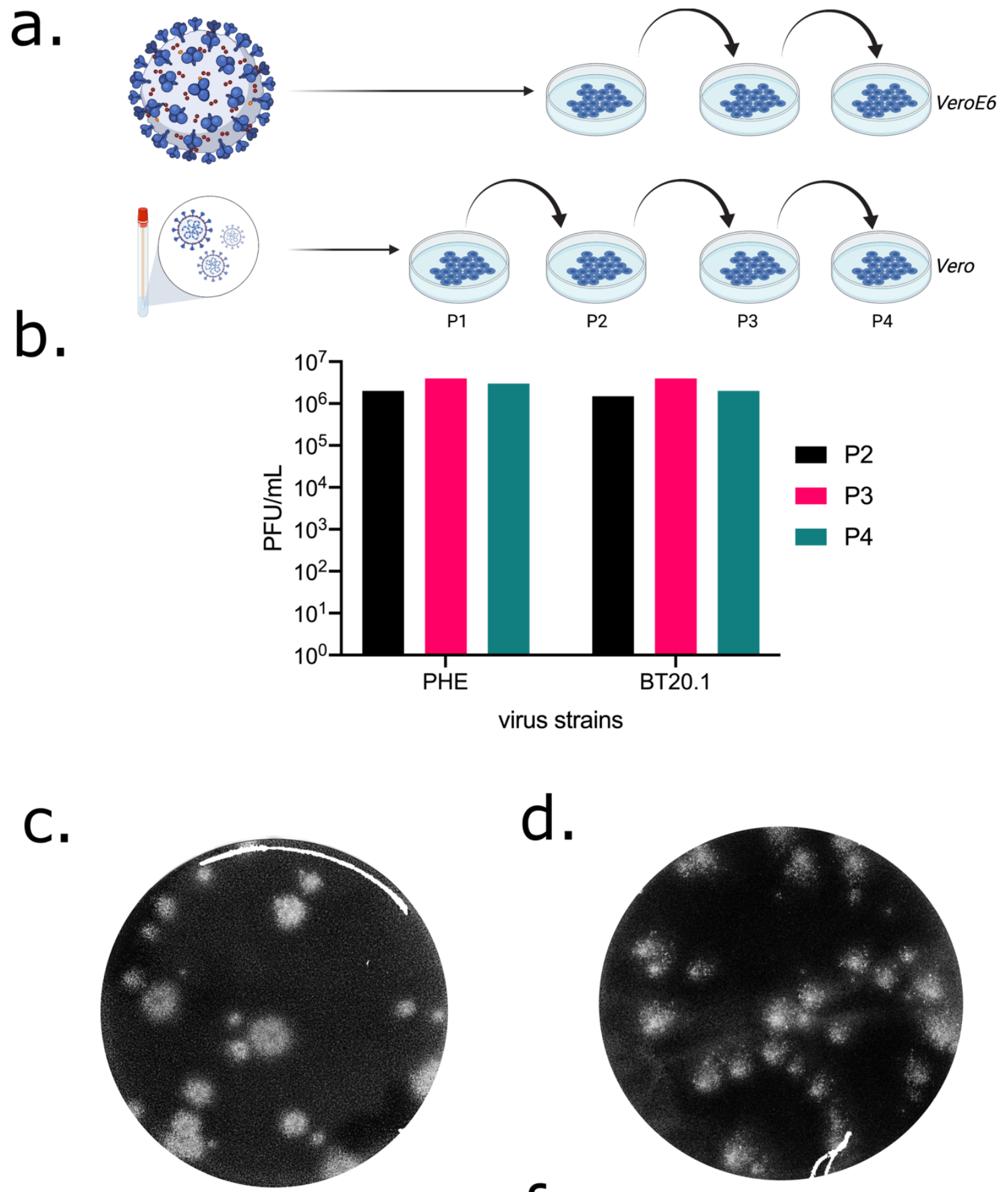

e
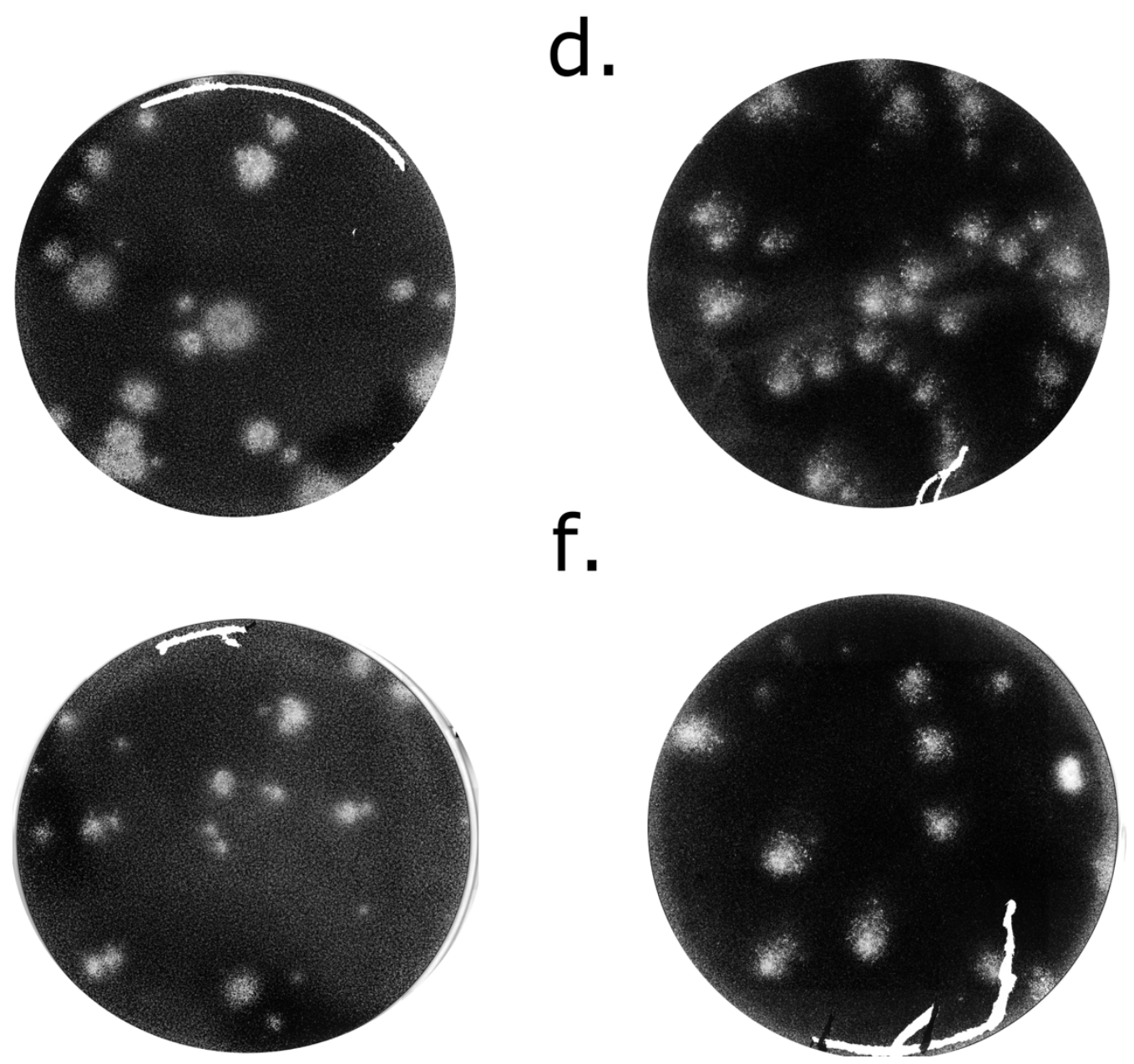
bioRxiv preprint doi: https://doi.org/10.1101/2021.07.16.452629; this version posted July $16,2021$. The copyright holder for this preprint (which was not certified by peer review) is the author/funder, who has granted bioRxiv a license to display the preprint in perpetuity. It is made available under aCC-BY-NC-ND 4.0 International license.

Comparison of SARS-CoV-2 evolution in vitro during passage in Vero and primary human airway cells

Figure 1. Isolation and passage of PHE and BT20.1 in Vero-derived cells. Schematic of SARS-CoV-2 isolation/serial passage series on VeroE6 or Vero cells for PHE and BT20.1 from isolation to P4 (a). Extracellular infectivity titres for stocks generated from P2-P4 VeroE6/Vero passage for PHE and BT20.1 using plaque assay protocol on Vero cells (b). Plaque visualisation of PHE (c) and BT20.1 (d) P4, and P2 (e and f) on Vero cells. Figures were generated with the aid of Biorender (https://biorender.com/).

\section{Sequencing of SARS-CoV-2 passage series in unmodified Vero- derived cells}

As we had successfully generated comparable in vitro passage series for two relevant isolates of SARS-CoV-2, we next determined what genetic changes, if any, occurred during passage in unmodified Veroderived cells. Whole genome sequences of our SARS-CoV-2 stocks at each passage were generated and minor sequence analysis ( $>5 \%$ minor allele frequency) was carried out, comparing variation arising to the Wuhan-Hu1 reference (NC_045512.2) genome sequence for SARS-CoV-2 (supplementary table 1). Unfortunately, the sequence depth and quality were not sufficient to reconstruct a whole genome sequences for BT20.1 P1 isolate material, likely due to insufficient viral material resulting from the initial isolation. Therefore, we focused our analysis on PHE P1-4 and BT20.1 P2-P4.

Analysing mutations in the PHE passage series we identified 4 changes (C8782T; T18488T; T28144C; A29596G) relative to Wuhan-Hu-1 consistently at $\sim 100 \%$ at all passages, likely reflecting fixation in the original virus stock (Fig 2A). These changes were considered intrinsic to that particular strain and were not analysed any further herein as we wished to focus on variants arising during passage. Sequencing confirmed the presence of D614 in Spike, consistent with it being an early SARSCoV-2 isolate.

Outwith the core changes described above, two major mutations were observed: a synonymous (T23605G) and non-synonymous out-offrame deletion (deletion of 24 nucleotides AATTCTCCTCGGCGGGCACGTAGTG 23597A; resulting in the replacement 
bioRxiv preprint doi: https://doi.org/10.1101/2021.07.16.452629; this version posted July 16, 2021. The copyright holder for this preprint (which was not certified by peer review) is the author/funder, who has granted bioRxiv a license to display the preprint in perpetuity. It is made available under aCC-BY-NC-ND 4.0 International license.

Comparison of SARS-CoV-2 evolution in vitro during passage in Vero and primary human airway cells

192

193

194

of of 9 amino acids [679-687; NSPRRARSV] in Spike with an isoleucine [I]) mapping to the polybasic cleavage site (PBCS) (Fig 2A). Deletion of the PBCS ablated the T23605G synonymous variant in the process. This occurred at P3, although the deletion was observed in the original P1 material from PHE. Furthermore, we detected 15 minor variants (nonconsensus) that had an allele frequency (AF) of $>5 \%$ in at least one sample of the passage series. These changes mapped to several genes and proteins of SARS-CoV-2, including ORF1AB, Spike, E, N, and ORF10. (supplementary table 1). Interestingly, we observed a cluster of three mutations occurring in the amino terminal domain (NTD) of Spike, appearing at P3 and rising in frequency at P4. Two of these Spike NTD mutations were similar to mutations occurring in VOCs: D215G and a deletion of 24 nucleotides (GCTATACATGTCTCTGGGACCAATGGTA21761G) resulting in a loss of 9 amino acids IHVSGTNGT (aa68-77). Additionally, we noticed a convergent mutation of L37 in $E$, detecting two mutations resulting in L37F and L37R. To determine the reproducibility of passage sequencing, an independent P4 PHE (P4B) was generated from P3 and sequenced, with very high levels of similarity between the two (supplementary table 1).

Like PHE, we identified core changes inherent to BT20.1 (Fig 2B), which were greater in number than PHE (10 vs 4 ), consistent with its later isolation (February 2020 versus June 2020) (supplementary table 1). These changes included, but were not limited to, D614G in Spike; R203K \& G204K in N; and an out-of-frame deletion of 5 nucleotides in ORF7A leading to its premature truncation. Like PHE, we identified mutations arising rapidly upon consecutive passage in Vero cells (i.e., were not detected at P2), including the non-synonymous mutations T293I in NSP12 and P812R in Spike. Both mutations had similar patterns of change in frequency and constituted the majority of sequences by P3. Like PHE, we also detected minor variants (9), including G1251V and S1252C in Spike. 
Comparison of SARS-CoV-2 evolution in vitro during passage in Vero and primary human airway cells
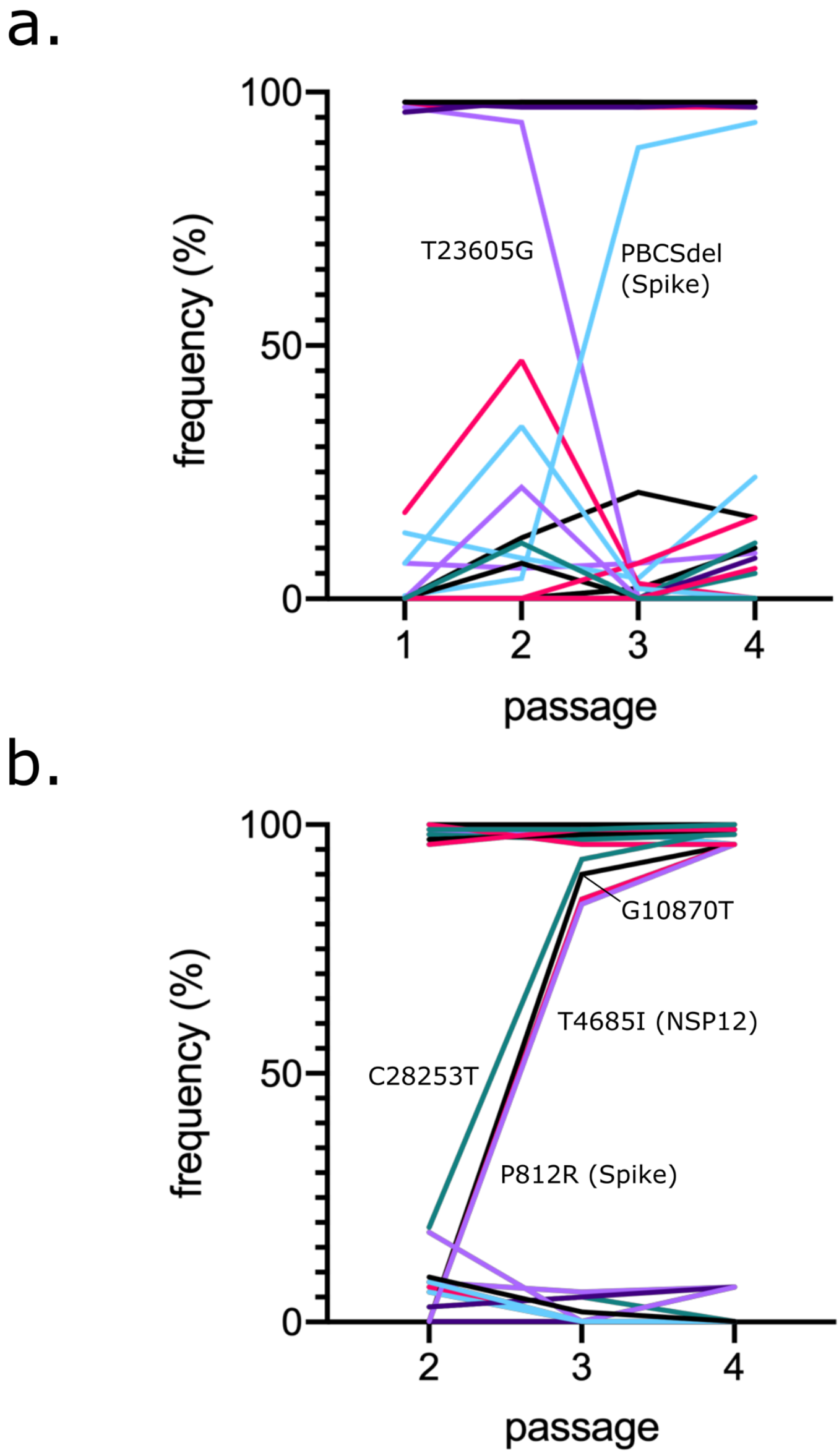
bioRxiv preprint doi: https://doi.org/10.1101/2021.07.16.452629; this version posted July $16,2021$. The copyright holder for this preprint (which was not certified by peer review) is the author/funder, who has granted bioRxiv a license to display the preprint in perpetuity. It is made available under aCC-BY-NC-ND 4.0 International license.

Comparison of SARS-CoV-2 evolution in vitro during passage in Vero and primary human airway cells

Figure 2. Analysis of PHE and BT20.1 whole genome sequences during Vero cell passage. Frequency of mutations detected for PHE (a) and BT20.1 (b) passage series on VeroE6 or Vero cells, respectively, relative to the reference sequence (Wuhan-Hu-1). Only sequences from P1-P4 (PHE) and P2-P4 (BT20.1) were analysed to facilitate adequate comparisons. Core changes are found consistently at high frequency and minor variants found at consistently low frequency (e.g. $<50 \%$ ). Only variants that significantly changed in frequency are marked on the graph. Colours do not reflect relationships between variants.

\section{Passage of SARS-CoV-2 on primary human airway cultures}

We next sought to investigate the effect of host cell type on subsequent viral evolution, as our previous analysis assessed the contribution of viral background to viral evolution in Vero-derived cells. To this end, in parallel, we passaged SARS-CoV-2 samples on welldifferentiated primary human airway epithelial cell cultures until P4, in a similar protocol as was carried out in Vero cells (Fig 3A). Primary cultures included WD-PNECs derived from two paediatric donors. For both PHE and BT20.1 robust infection and passage on WD-PNECs was established. For PHE, WD-PNECs were initially infected at MOI of 0.1 and virus harvested at 2-3 dpi, using the original P1 virus material. This was repeated for BT20.1, except unlike PHE, BT20.1 was directly isolated on primary cultures from the obtained clinical material. SARS-CoV-2 grew well in the primary cultures, reaching titres of $\sim 10^{6} \mathrm{pfu} / \mathrm{mL}$ in 2-3 days in the apical compartment. Samples at each passage were subjected to sequencing as outlined above and analysed in a similar manner to those from the Vero cell passage series. For BT20.1 only P2, P3 and P4 were sequenced to compare with the data available for the equivalent Vero passage series.

In contrast to what was observed in VeroE6 cells, we did not detect any major genetic changes in PHE following passage in WD-PNECs (Fig 3B). However, we did identify the PBCS deletion at low levels in minor variant analysis, but never reaching majority. Together with PBCS we found 34 changes as minor variants. From passage to passage, these mutations appeared, and disappeared, stochastically. Similarly, in BT20.1, unlike the Vero cell passage, we did not find corresponding mutations in 
Comparison of SARS-CoV-2 evolution in vitro during passage in Vero and primary human airway cells

259 Nsp12 or Spike (Fig 3C). However, we identified a single amino acid 260 deletion, Y1595, in NSP3. Intriguingly, this variant was maintained 261 throughout the passage series at a moderate frequency of $\sim 45 \%$. At each 262 passage, where possible, SARS-CoV-2 was titrated by plaque assay on 263 Vero cells (SFig 2). However, we were unable to obtain titres for PHE and 264 BT20.1 passage P3 and P1, respectively. We noticed slightly reduced 265 titres of BT20.1 in primary cells at P4 compared to earlier passages, 266 which was not observed for PHE (sFig2). WD-PNEC-grown viruses had 267 less obvious plaques (sFig 3 A and B) and no evidence of cell-to-cell 268 fusion was identified, even for BT20.1 (sFig 3 C). Similar to passage in 269 Vero cells we identified two mutations in Spike (G1251V and S1252C), 270 which appeared at low frequencies $(<10 \%)$ and never increased (table 271 1). 
Comparison of SARS-CoV-2 evolution in vitro during passage in Vero and primary human airway cells

a.

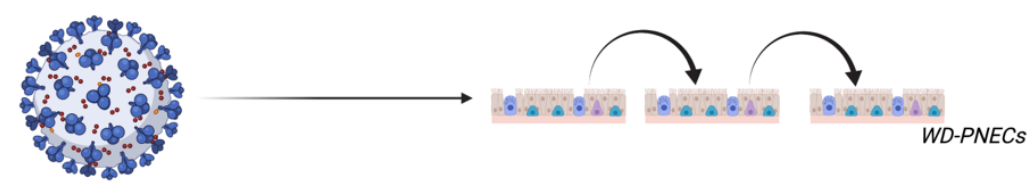

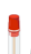
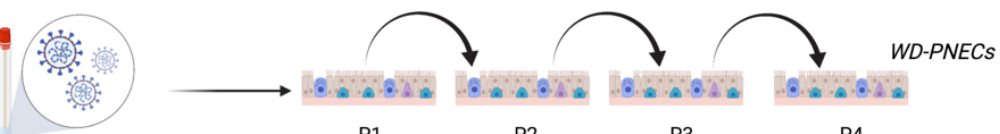

b.

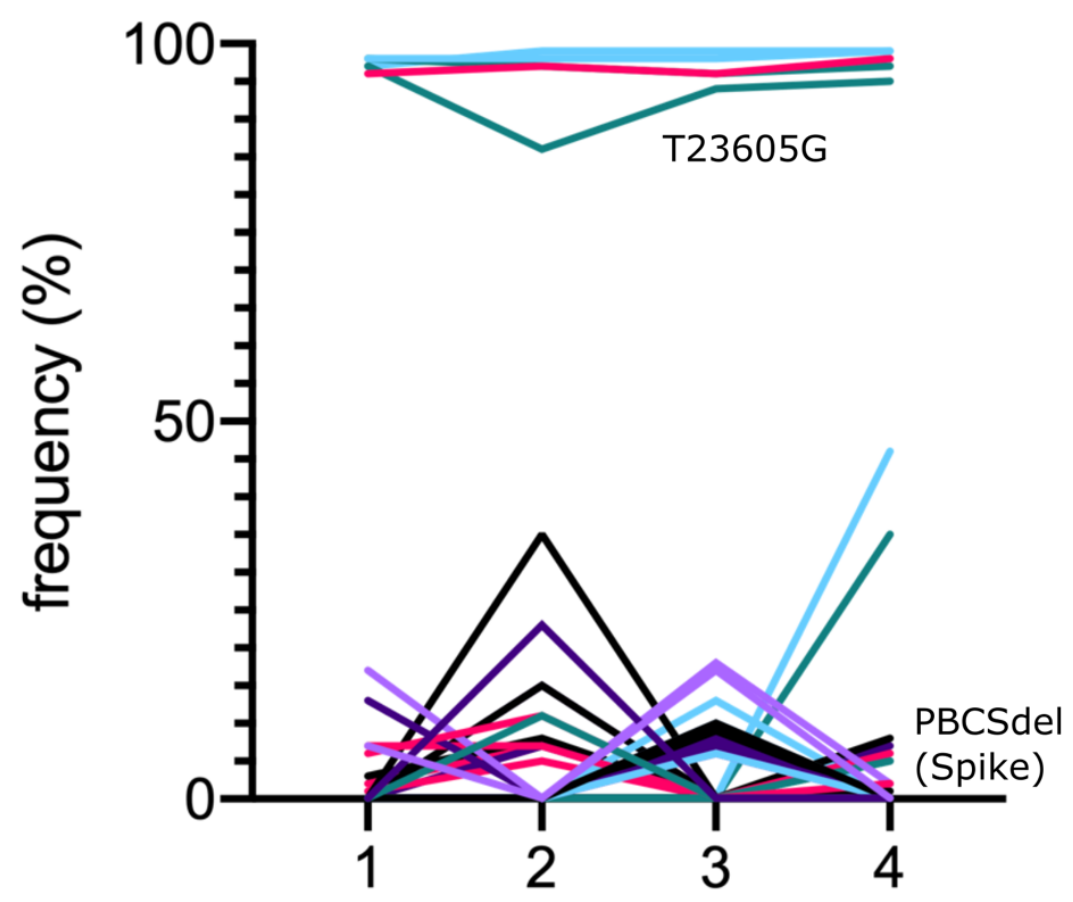

C.

passage

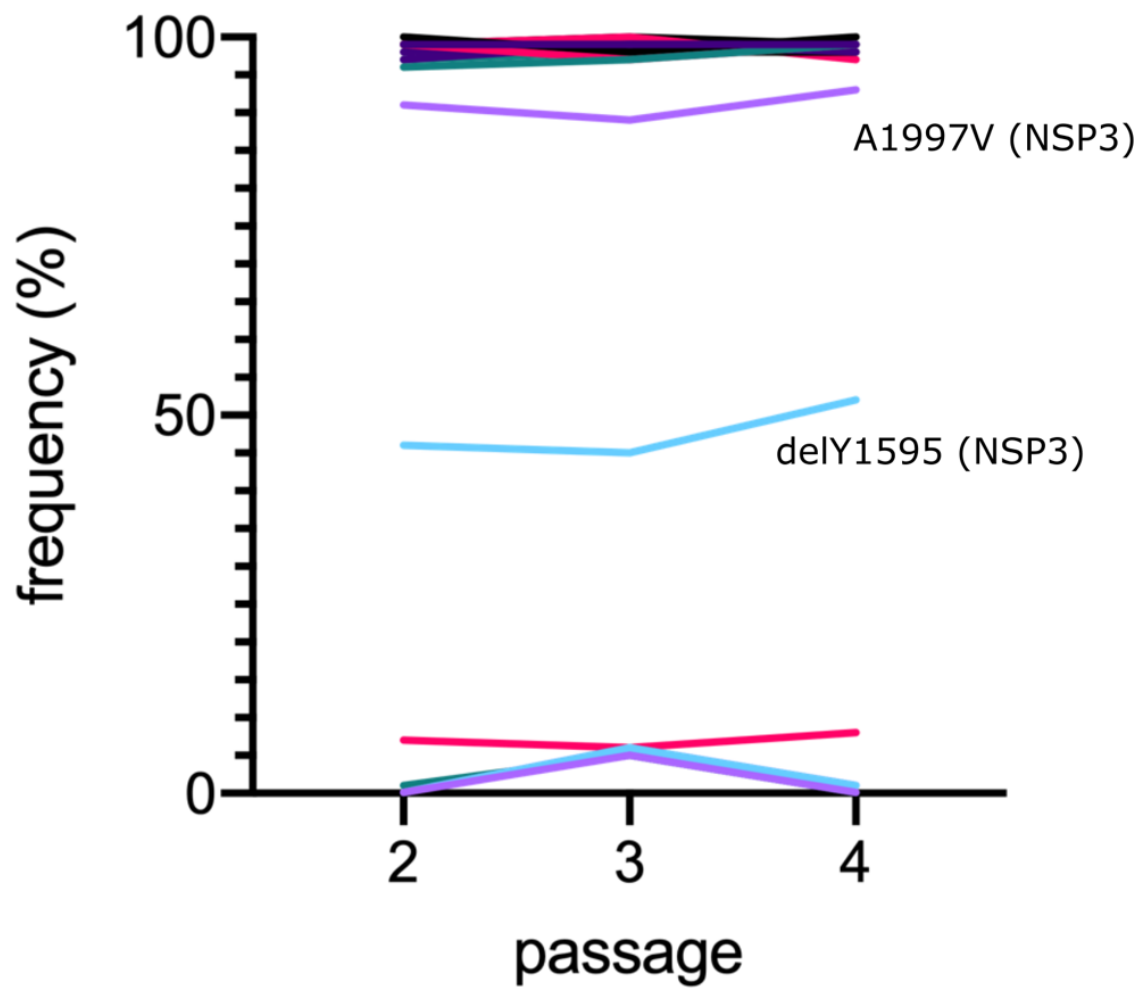


bioRxiv preprint doi: https://doi.org/10.1101/2021.07.16.452629; this version posted July $16,2021$. The copyright holder for this preprint (which was not certified by peer review) is the author/funder, who has granted bioRxiv a license to display the preprint in perpetuity. It is made available under aCC-BY-NC-ND 4.0 International license.

Comparison of SARS-CoV-2 evolution in vitro during passage in Vero and primary human airway cells

Figure 3. Analysis of PHE and BT20.1 whole genome sequences during WDPNECs passage. Schematic of SARS-CoV-2 isolation/passage series on WD-PNECs for PHE and BT20.1 (a). Frequency of mutations detected for PHE (b) and BT20.1 (c) passage series on WD-PNECs, respectively, relative to the reference sequence (Wuhan$\mathrm{Hu}-1$ ). Only sequences from P1-P4 (PHE) and P2-P4 (BT20.1) were analysed. PHE P1 is the original stock material obtained and hence is the same sequence as PHE P1 in figure 2. Core changes were found consistently at high frequency and minor variants found at consistently low frequency (e.g. $<50 \%$ ). Only variants that significantly changed in frequency are marked on the graph. Colours do not reflect relationships between variants. Figures were generated with the aid of Biorender (https://biorender.com/).

Phenotypic differences between SARS-CoV-2 'PHE' and 'BT20.1'

P4

Our data showing host cell dependency in viral evolution suggested differential fitness for specific viral genotypes (e.g., Vero cell-derived mutations that were not observed in WD-PNECs were less fit in primary cells). To test this hypothesis, we focused subsequent analysis on PHE and BT20.1 Vero P4 stocks with clear genetic differences between them, including the PHE PBCS deletion in Spike, and the P812R (Spike) and NSP12 mutations in BT20.1. To this end, we wished to directly compare the growth and multi-cycle replication kinetics of both strains in cell culture models of infection. To achieve this, we carried out a comparison of growth kinetics in several cell culture models, including Vero cells, VeroE6 cells modified to express human ACE2 and TMPRSS2 (VAT) (Rihn et al., 2021), and WD-PNECs (adult nasal)

(Fig 4A-C). Of note, unmodified Vero and VeroE6 cells do not express human ACE2 and have very low levels of TMPRSS2 (Matsuyama et al., 2020). In Vero cells, SARS-CoV-2 grew to peak extracellular infectivity titres by $\sim 48$ hpi with titres of $\sim 10^{6} \mathrm{pfu} / \mathrm{mL}$. We noticed a growth attenuation of BT20.1 in Vero cells compared to PHE (Fig 4A). Comparing virus growth in VAT cells (Fig 4B), both viruses grew better but the relative attenuation of BT20.1 was not observed in VAT cells. In contrast to previous Vero cell experiments, we observed a prominent growth defect of PHE compared to BT20.1 at early time points during infection (24/48 h) in WD-PNECs. However, both viruses reached similar titres by 72 hpi (Fig 4C). Together these data 
bioRxiv preprint doi: https://doi.org/10.1101/2021.07.16.452629; this version posted July 16, 2021. The copyright holder for this preprint (which was not certified by peer review) is the author/funder, who has granted bioRxiv a license to display the preprint in perpetuity. It is made available under aCC-BY-NC-ND 4.0 International license.

Comparison of SARS-CoV-2 evolution in vitro during passage in Vero and primary human airway cells

309 clearly demonstrate phenotypic differences between our Vero cell310 passaged viruses, demonstrating a critical role for the PBCS for efficient replication in primary cells. 
Comparison of SARS-CoV-2 evolution in vitro during passage in Vero and primary human airway cells

a.
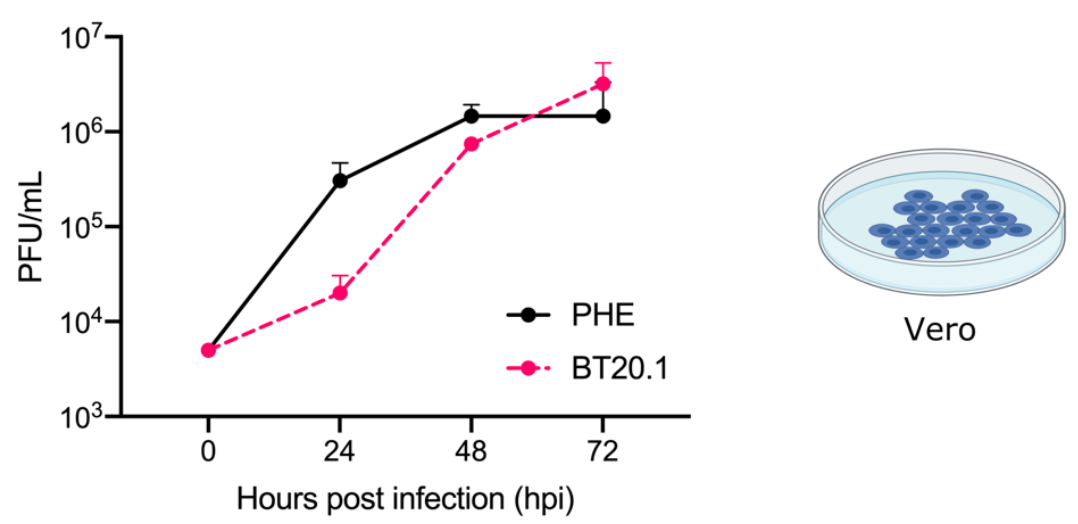

b.
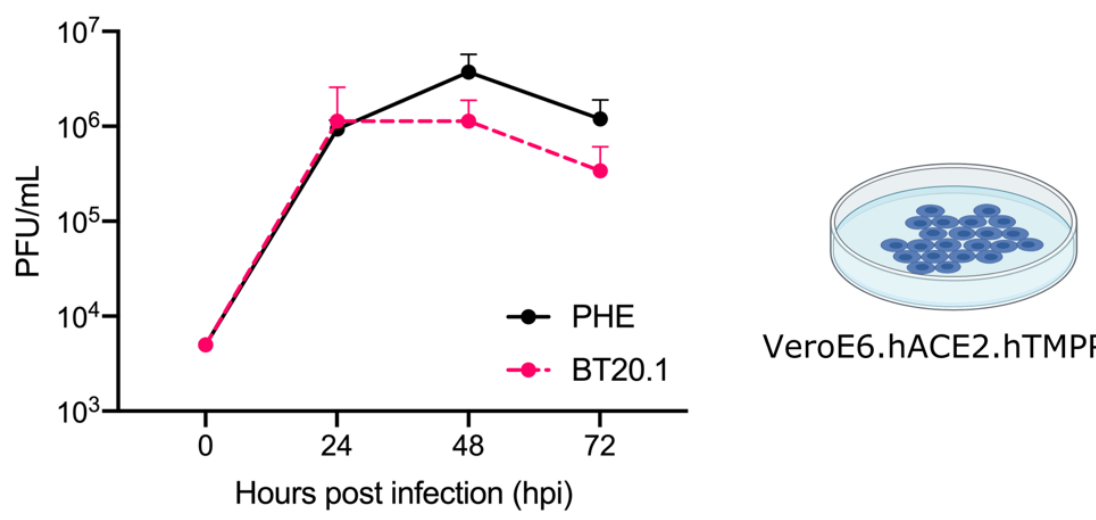

VeroE6.hACE2.hTMPRSS2

C.

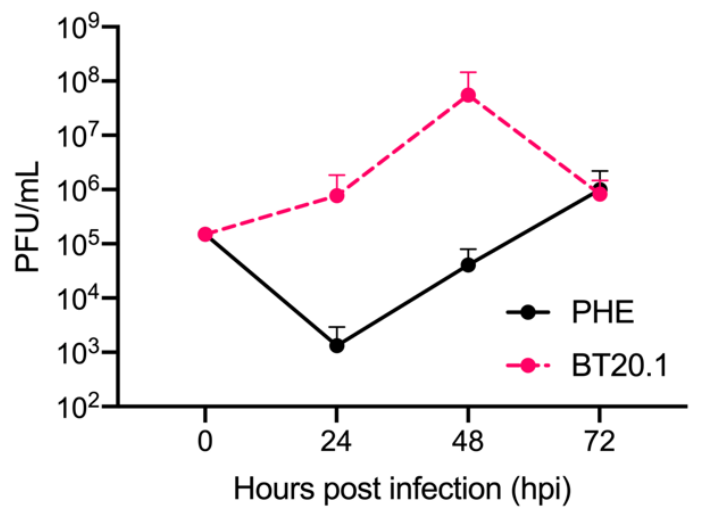

WD-PNECS 
bioRxiv preprint doi: https://doi.org/10.1101/2021.07.16.452629; this version posted July 16, 2021. The copyright holder for this preprint (which was not certified by peer review) is the author/funder, who has granted bioRxiv a license to display the preprint in perpetuity. It is made available under aCC-BY-NC-ND 4.0 International license.

Comparison of SARS-CoV-2 evolution in vitro during passage in vero and primary human airway cells

PNECs) for PHE P4 (VeroE6) and BT20.1 P4 (Vero) on Vero (a), VeroE6 cells expressing human ACE2 and human TMPRSS2 (b), and adult WD-PNECs from 3 donors (c). Titres for Vero-derived cells are shown as means +/- SEM for triplicate wells and are representative of two independent experiments. Titres for WD-PNECs are shown as means +/- SEM for single wells from 3 donors. Data using BT20.1 are presented here as averages from 3 donors but have also been incorporated into a sister paper using separated, individual donor data (Broadbent et al., 2021 in submission). Figures were generated with the aid of Biorender (https://biorender.com/). 
bioRxiv preprint doi: https://doi.org/10.1101/2021.07.16.452629; this version posted July 16, 2021. The copyright holder for this preprint (which was not certified by peer review) is the author/funder, who has granted bioRxiv a license to display the preprint in perpetuity. It is made available under aCC-BY-NC-ND 4.0 International license.

Comparison of SARS-CoV-2 evolution in vitro during passage in Vero and primary human airway cells

\section{Discussion}

Investigation of the patterns of SARS-CoV-2 genetic diversity worldwide during outbreaks has already facilitated a genetic-based nomenclature of lineages and has also highlighted the emergence of functionally-relevant mutations, such as D614G in Spike, and those contained in extant VOCs (Harvey et al., 2021). Complementary to this, in vitro systems are an incredibly useful and tractable means to understand the forces influencing this viral evolution, in particular those that mimic in vivo-relevant conditions, such as WD-PNECs (Hou et al., 2020).

Our data and that of others demonstrate significant standing genetic diversity in viral populations in vitro that can be acted upon by rapid evolutionary processes. Although also observed in our work, from early in the study of SARS-CoV-2 evolution in Vero-like cells, it was revealed that the virus readily diversifies during culture with the most evident being mutations mapping to the PBCS of Spike (Davidson et al., 2020; Klimstra et al., 2020; Lamers et al., 2021; Ogando et al., 2020; Pohl et al., 2021). Consistent with our work, other studies have identified enhanced genetic stability, in particular of the PBCS only, during passage of one strain in Calu3 or primary airway organoids (Lamers et al., 2021). One striking finding of our work, which builds on previous studies, is that on several occasions for both isolates we observed a rapid increase in frequency of specific mutations in the PBCS and independently of it (PBCS deletion \& P812R in Spike, and T293I in NSP12) to near fixation over the course of a couple of passages in Vero cells. These patterns suggest a selective phenotypic advantage in that particular cell culture system. Similar changes (including P812R and the NTD deletion) were identified in other studies (Dieterle et al., 2020; Ramirez et al., 2021). The fact that identical mutations arise independently (e.g., loss of the PBCS and P812R) is highly suggestive of convergent evolution, perhaps toward a similar phenotype. Our work on the loss of the PBCS in 
bioRxiv preprint doi: https://doi.org/10.1101/2021.07.16.452629; this version posted July 16, 2021. The copyright holder for this preprint (which was not certified by peer review) is the author/funder, who has granted bioRxiv a license to display the preprint in perpetuity. It is made available under aCC-BY-NC-ND 4.0 International license.

Comparison of SARS-CoV-2 evolution in vitro during passage in Vero and primary human airway cells

355

Vero cells and its association with attenuation in WD-PNECs is consistent with previous reports. However, it is noteworthy that we did not observe deletion or mutations in and around the PBCS during passage of BT20.1 in Vero cells.

In addition to the loss of the PBCS, we observed P812R in Spike and T293I in NSP12, although we were not able to associate them with changes in virus growth in WD-PNECs due to a lack of an additional comparable 'wild-type' isolates. However, the fact that parallel passage in WD-PNECs did not result in their increased frequency suggests that they confer a hitherto unrecognised disadvantage in the primary epithelial cell system. P812R is a non-conservative change and rapidly rose to nearfixation alongside NSP12 in BT20.1 in Vero cells. P812 sits near the S2' cleavage site and is a highly conserved position in SARS-CoV-2. However, non-P residues (e.g. serine) were occasionally found in nature but are rare (https://nextstrain.org/), which suggests a functional defect in vivo. Interestingly, P812R was observed before, in at least two other studies, associated with a change in Spike activity using full-length SARS-CoV-2 and one using chimeric vesicular stomatitis virus encoding SARS-CoV-2 Spike (Dieterle et al., 2020; Ramirez et al., 2021). Like previous work, we noted an association of P812R with enhanced cell-to-cell fusion when BT20.1 grown on Vero cells is compared to that grown in WD-PNECs (sFig 3). It was suggested that P812R generated a novel PBCS at the S2' site (Ramirez et al., 2021). Cleavage by furin-like proteases could thus compensate for lack of TMPRSS2-mediated proteolysis and activation in Vero cells. Although it is possible that P812R confers a similar phenotypic change as the PBCS deletion, it is not likely to be identical, given the clear differences in growth between PHE and BT20.1 in Vero cells and WDPNECs. Along with P812R in S, BT20.1 carried a mutation in NSP12 (T4685I/T293I), which is the viral RNA-dependent RNA polymerase. The mutation sits on the surface in close proximity to a zinc-binding site of the interface domain that mediates intra-NSP12 interactions and interactions 
Comparison of SARS-CoV-2 evolution in vitro during passage in Vero and primary human airway cells

between NSP12 and other polymerase co-factors, such as NSP8 (Hillen et al., 2020). Given the linkage between P812R and T4685I, further molecular virological work using isogenic viruses generated through reverse genetics is required to ascertain the impact of this mutation in relevant cell models. The mutations T4685I arose with P812R possibly suggesting genetic linkage, although this remains to be determined.

It is of interest that BT20.1 carries a deletion in ORF7A that results in a frameshift and C-terminal truncation of the protein, likely ablating the transmembrane domain and tail. ORF7A is a type 1 transmembrane protein and it has numerous putative functions involved in host-pathogen interactions and immune evasion (Nemudryi et al., 2021). ORF7A truncations in SARS-CoV-2 isolates have been discovered before, possibly associated with reduced capacity to subvert the innate immune response (Nemudryi et al., 2021). However, the previous work was carried out using non-clinically relevant cell models, such as Vero or HEK-derived lines. Our work suggests that full-length ORF7A is not required for replication in Vero or WD-PNECs and likely serves an accessory function that may affect replication and/or transmission in particular circumstances.

Not only did we observe changes reaching near-fixation in our dataset we also identified several lower frequency mutations in our viral populations. Consistent with this variation within a stock, we also noticed plaque size variation in passage stocks suggestive of functional differences between viral sub-clones (Fig 1 E and F). We detected an inframe deletion of a single codon in the C-terminus of NSP3, located in the Y1 domain, which is located on the cytoplasmic face of the virusremodelled ER membrane, where it may regulate replication complex stability by interacting with NSP4 (Lei et al., 2018). NSP3 itself is a multifunctional protein involved in numerous viral processes. The fact that the deletion did not rise to fixation suggests that it is at a competitive disadvantage compared to wild-type. The mutation in NSP3 is also 
bioRxiv preprint doi: https://doi.org/10.1101/2021.07.16.452629; this version posted July 16, 2021. The copyright holder for this preprint (which was not certified by peer review) is the author/funder, who has granted bioRxiv a license to display the preprint in perpetuity. It is made available under aCC-BY-NC-ND 4.0 International license.

Comparison of SARS-CoV-2 evolution in vitro during passage in Vero and primary human airway cells

417 interesting because it is maintained at a moderate frequency. Of considerable interest is the overlap between variations observed in Vero cells and that of VOCs, especially in the NTD of Spike. We observed three mutations in the NTD in PHE P3 and P4: E180K, D215G, and a deletion resulting in the loss of 9 amino acids. Variants identified in this study mapping to the ectodomain of Spike are marked on a structural model (sFig 4). For D215G and the deletion, these mutations are similar to those in VOCs, such as alpha and beta variants. Regarding mutations in NTD loops, several VOCs have convergently modified the amino acid identity of the loop. While in vivo this may be the result of antibody selection, in our system there are no antibodies, which suggests a role for NTD mutations independent of antibody selection. The rise in frequency is suggestive of a fitness advantage of these mutations. Further work is required to determine the function of the NTD of Spike and the impact of these mutations on the virus life cycle.

While general trends were similar between our two isolates in Vero cells (i.e., mutations rising to high frequency), specific mutations observed were not. It is likely that evolution of key mutations reflect inherent biological differences in viruses and not subtle changes in passaging conditions. In PHE, loss of the PBCS occurred, which was not observed in BT20.1, and vice versa regarding P812R and NSP12. This is consistent with an effect dependent on viral input or strain or genetic background through epistatic interactions between mutations, such as D614G in Spike. However, in numerous reports, isolation and passage of SARS-CoV-2 on Vero cells selected for a loss of the PBCS, which was not observed in our BT20.1 passage series. Alternatively, the mutation P812R could functionally achieve the same phenotype as the deletion of the PBCS, although our primary cell infection model where PHE was attenuated compared to BT20.1, would suggest that this is not the case.

By comparing evolution of the same isolates in two distinct cell culture systems, we observed a dependence on host cell substrate on 
Comparison of SARS-CoV-2 evolution in vitro during passage in Vero and primary human airway cells

448

449

450

451

452

453

454

455

456

457

458

459

460

461

462

463

464

465

466

467

468

downstream virus evolution. Namely, passage in WD-PNECs resulted in enhanced stability of SARS-CoV-2 genetic diversity at the consensus level. While the PBCS, P812R and NSP12 changes were identified in PHE and BT20.1 when grown in Vero cells, these changes did not rise to high frequencies in WD-PNECs. Differential accumulation of mutations may reflect distinct host cellular environments encountered upon passage in Vero or WD-PNECs. This reflects major differences in these cell substrates, including i) species and tissue differences; ii) reduced levels of TMPRSS2 in Vero cells; iii) reduced innate immune response in Vero cells as they are deficient in type 1 interferon production (Emeny \& Morgan, 1979). However, what affects the rise in $P 812 R / N S P 12$ mutation remains unknown. Future work will assess the effect of these changes in BT20.1 upon replication in WD-PNECS. Additionally, during passage of BT20.1 in WD-PNECs we identified a deletion in Nsp3, although the relevance and mechanism of this change is unknown.

In conclusion, by studying the evolution of SARS-CoV-2 during passage in distinct cellular substrates we shed light on the forces that shape viral fitness, unveiling a collaboration between both viral and host factors in driving SARS-CoV-2 genetic diversity, which helps define the molecular correlates of fitness in the natural target cells. Finally, on a practical note, our results support close characterisation of virus stocks for experimentation in vitro and in vivo and suggest ways to mitigate unwanted cell culture artefacts, critical for understanding host-pathogen interactions and identification of antiviral interventions. 
Comparison of SARS-CoV-2 evolution in vitro during passage in Vero and primary human airway cells

Figure 1. Isolation and passage of PHE and BT20.1 in Vero-derived cells. Schematic of SARS-CoV-2 isolation/serial passage series on VeroE6 or Vero cells for PHE and BT20.1 from isolation to P4 (a). Extracellular infectivity titres for stocks generated from P2-P4 VeroE6/Vero passage for PHE and BT20.1 using plaque assay protocol on Vero cells (b). Plaque visualisation of PHE (c) and BT20.1 (d) P4, and P2 (e and f) on Vero cells. Figures were generated with the aid of

Biorender (https://biorender.com/).

Figure 2. Analysis of PHE and BT20.1 whole genome sequences during Vero cell passage. Frequency of mutations detected for PHE (a) and BT20.1 (b) passage series on VeroE6 or Vero cells, respectively, relative to the reference sequence (Wuhan-Hu-1). Only sequences from P1-P4 (PHE) and P2-P4 (BT20.1) were analysed to facilitate adequate comparisons. Core changes are found consistently at high frequency and minor variants found at consistently low frequency (e.g. <50\%). Only variants that significantly changed in frequency are marked on the graph. Colours do not reflect relationships between variants.

Figure 3. Analysis of PHE and BT20.1 whole genome sequences during WD-PNECs passage. Schematic of SARS-CoV-2 isolation/passage series on WD-PNECs for PHE and BT20.1 (a). Frequency of mutations detected for PHE (b) and BT20.1 (c) passage series on WDPNECs, respectively, relative to the reference sequence (Wuhan-Hu-1). Only sequences from P1-P4 (PHE) and P2-P4 (BT20.1) were analysed. PHE P1 is the original stock material obtained and is hence the same sequence as PHE P1 in figure 2. Core changes are found consistently at 
Comparison of SARS-CoV-2 evolution in vitro during passage in Vero and primary human airway cells

505

506

507

508

509

510

511

512

513

514

515

516

517

518

519

520

521

522

523

524

525

526

527

528

529

530

531

532

533

high frequency and minor variants found at consistently low frequency (e.g., <50\%). Only variants that significantly changed in frequency are marked on the graph. Colours do not reflect relationships between variants. Figures were generated with the aid of Biorender (https://biorender.com/).

Figure 4. Comparison of PHE P4 (Vero) and BT20.1 P4 (Vero) growth on different cell substrates. Multicycle growth curves (MOI 0.01 for Vero or 0.1 for WD-PNECs) for PHE P4 (VeroE6) and BT20.1 P4 (Vero) on Vero (a), VeroE6 cells expressing human ACE2 and human TMPRSS2 (b), and adult WD-PNECs from 3 donors (c). Titres for Veroderived cells are shown as means +/- SEM for triplicate wells and are representative of two independent experiments. Titres for WD-PNECs are shown as means +/- SEM for single wells from 3 donors. Data using BT20.1 have been reproduced here as averages from 3 donors but have also been incorporated into a sister paper using separated, individual donor data (Broadbent et al., 2021 in submission). Figures were generated with the aid of Biorender (https://biorender.com/).

\section{sTable 1. Frequency of variants in reference to Wuhan-Hu-1} identified in this study. Variants only shown where there was at least one instance of frequency $>5 \%$. Where undetectable an arbitrary value of 0.1 was assigned. Frequency data is highlighted by colour (green for higher, yellow for lower). Mutations have been assigned status of core, variant or minor. Additionally, for each variant, data for nucleotide location, reference and variant nucleotides, gene \& protein location, and consequence (e.g., synonymous [S] or non-synonymous [NS]) are shown. 

made available under aCC-BY-NC-ND 4.0 International license.

Comparison of SARS-CoV-2 evolution in vitro during passage in Vero and primary human airway cells

sFig 1. Fusogenicity of PHE and BT20.1 P4 on Vero cells. Higher magnification images of plaque visualisation of PHE (a) and BT20.1 (b) P4 on Vero cells from the same images shown in Figure 1.

537

sFig 2. Growth kinetics of PHE and BT20.1 during passage in WDPNECs. Infectivity titres for material generated from isolation/passage of PHE and BT20.1 on WD-PNECs.

sFig 3. Plaque morphology of SARS-CoV-2 grown in WD-PNECs. Plaque visualisation of PHE (a) and BT20.1 (b) P4 on Vero cells. Higher magnification images of plaque visualisation of BT20.1 (c) P4 on Vero cells from the same images shown (b).

sFig 4. Location of Spike mutant variants observed in this study on model structure of a single Spike monomer in the pre-fusion state (PDB 7C2L

from (Chi et al., 2020)). Variants identified in the Spike cytoplasmic tail (G1251V and S1252C) are not shown. 
Comparison of SARS-CoV-2 evolution in vitro during passage in Vero and primary human airway cells

\section{Materials and methods}

557

\section{Continuous cell line culture}

559 In this study, 3 continuous cell lines were used: Vero wildtype (number), Vero E6, and Vero E6 expressing human ACE2 and TMPRSS2 (VAT) (Rihn et al., 2021). All cells were grown in DMEM (5\% FCS v/v) with antibiotics. VAT cells were maintained in the presence of additional antibiotics to select of cells carrying transgenes. Cell lines were routinely tested for mycoplasma contamination and no evidence of contamination was detected.

\section{WD-PNECS}

Nasal epithelial cells from preschool age children with recurrent wheeze (for initial passaging) and from healthy adults (for final comparison of PHE and BT20.1 P4 viruses) were obtained by brushing of the nasal turbinates with an interdental brush (DentoCare). Cells were cultured in monolayer until passage 3 then seeded onto collagen-coated Transwells ( $6 \mathrm{~mm}, 0.4$ $\mu \mathrm{m}$ pore size; Corning). Once confluent the apical medium was removed to create an air-liquid interface which, together with specialised media (Pneumacult ALI, Stemcell Technologies), triggered differentiation (Broadbent et al. 2016. Broadbent et al. 2020). Complete differentiation (after a minimum of $21 \mathrm{~d}$ ) was confirmed by an intact culture, extensive cilia coverage and mucus production.

\section{Viruses}

581 Two SARS-CoV-2 isolates were used throughout this study, including 'PHE' and 'BT20.1'. PHE was provided as an early passage isolate on VeroE6 cells while BT20.1 was provided directly as a nasopharyngeal swab in virus transport media clinical material from a positive case from 
Comparison of SARS-CoV-2 evolution in vitro during passage in Vero and primary human airway cells

Belfast in June 2020. Stocks were prepared in Vero or VeroE6 cells in DMEM containing $2.5 \%$ FCS $(\mathrm{v} / \mathrm{v})$ infected at a low MOI ( 0.001). Infections were harvested when maximal cytopathic effect was noted, usually between 3-4 days post infection. Infected culture supernatant was harvested, clarified by centrifugation and stored at $-80^{\circ} \mathrm{C}$. WD-PNECs were apically infected with SARS-CoV-2 for $1 \mathrm{~h}$, after which the inoculum was removed and the apical surface gently rinsed with DMEM. Virus was harvested from WD-PNECs by incubation of the apical surface with DMEM for $5 \mathrm{~min}$ at room temperature in the absence of serum. Harvested virus was immediately stored at -80. All SARS-CoV-2 work was carried out under BSL3 conditions in a dedicated facility in QUB.

\section{Plaque assays}

Our plaque assay protocol is based on the methodology available here: https://www.protocols.io/view/viral-titration-of-sars-cov-2-by-plaqueassay-semi-be4zjgx6. Near confluent monolayers of Vero cells in 24 or 6 well plates were infected. On the day of titration growth media was replaced with DMEM (0\% FCS) $(250 \mu \mathrm{L})$. Virus dilutions were prepared in plate and incubated for 30 min after which the $2 x$ overlay medium (containing 2\% agarose) was added. Plates were incubated for 3 days at $37^{\circ} \mathrm{C}$. At 3 dpi PFA (8\%) was added to the cultures and cells fixed/inactivated for at least $20 \mathrm{~min}$. Following fixation, the PFA was removed and monolayers stained for 10 min using crystal violet $(1 \% \mathrm{w} / \mathrm{v}$ in ethanol 20\%). Following staining, residual crystal violet solution was removed, plates were rinsed in water and submerged in Chemgene prior to drying and removing from the hood for visualisation and quantification. To calculate PFU/mL, plaques at a dilution were quantified, the precipice of this number used, and multiplied by the dilution factor (4). For visualisation of plaque assays, whole plates were scanned using a Celigo imaging cytometer (Nexcelom Bioscience). 
bioRxiv preprint doi: https://doi.org/10.1101/2021.07.16.452629; this version posted July 16, 2021. The copyright holder for this preprint (which was not certified by peer review) is the author/funder, who has granted bioRxiv a license to display the preprint in perpetuity. It is made available under aCC-BY-NC-ND 4.0 International license.

Comparison of SARS-CoV-2 evolution in vitro during passage in Vero and primary human airway cells

\section{Virus whole genome sequencing}

Virus whole genome sequencing used methods developed by the ARTIC network (https://artic.network; (Tyson et al., 2020)) and the COG-UK Consortium. Culture supernatants were inactivated by addition of Triton $\mathrm{X}-100$ to $1.5 \%(\mathrm{v} / \mathrm{v})$. Viral RNA (total nucleic acid) was extracted from inactivated samples $(200 \mu \mathrm{L})$ using the MagNA Pure Compact instrument and MagNA Pure Compact Nucleic Acid Isolation Kit I (Roche Molecular Systems Inc, Burgess Hill, UK). Purified nucleic acid was eluted into 100 $\mu \mathrm{L}$ and used immediately or stored at $-80^{\circ} \mathrm{C}$. For first-strand CDNA synthesis, nucleic acid ( $5 \mu \mathrm{L})$ was used as template for reverse transcription using LunaScript $®$ RT SuperMix Kit (New England Biolabs, Hitchin, UK) in $20 \mu \mathrm{L}$ reaction volume. Primers were annealed $\left(65^{\circ} \mathrm{C}\right.$, 5 min, snap-cool on ice) prior to addition of reverse transcriptase. Reactions were incubated at $42^{\circ} \mathrm{C}$ (50 min) then stopped at $70^{\circ} \mathrm{C}$ (10 min). The resulting cDNA was used immediately for PCR or stored at $20^{\circ} \mathrm{C}$. In brief, these were run as two separate multiplex PCR "pools" (A \& $B$ ) using the ARTIC version 3 primer set (ARTIC nCoV-2019 V3 Panel, IDT DNA Inc, Leuven, Belgium; https://github.com/artic-network/primerschemes/tree/master/nCoV-2019) and Q5 DNA polymerase mastermix (New England Biolabs). Following PCR, the amplicons from pools A \& B were combined, and the resulting pooled amplicons (98 x 450 bp overlapping tiled amplicons, spanning the SARS-CoV-2 genome) were purified using Kapa HyperPure beads (Roche Molecular Systems Inc) and quantified using a Qubit fluorometer and dsDNA HS Assay Kit (Thermo Fisher Inc, Manchester, UK). Amplicon sequencing libraries were prepared using the Nextera DNA Flex library kit according to the manufacturer's instructions (Illumina Ltd., Cambridge, UK). Libraries were sequenced on a MiSeq (Illumina) using a MiSeq Reagent Kit v2 and 2 × 151 bp pairedend sequencing protocol (Illumina).

\section{Sequence analysis}


Comparison of SARS-CoV-2 evolution in vitro during passage in Vero and primary human airway cells

647 The FASTQ files were uploaded into the Galaxy web platform, and we 648 used the public server at usegalaxy.eu to analyse the data (Afgan et al., 649 2018). The workflow used was specially optimized for Illumina650 sequenced based ARTIC pair end data with the intention to detect allelic 651 variants (AVs) in SARS-CoV-2 genomes (Maier et al., 2021). This analysis converted FASTQ data to annotated AVs through a series of steps that include QC, trimming ARTIC primer sequences off reads with the iVar package, mapping using bwa-mem, deduplication, AV calling using lofreq, and filtering $A V s$ that both occurred at an allele frequency $(A F) \geq 5 \%$, and were supported by $\geq 10$ reads. As we could not determine the background frequency of mutations we focused on those variants with a minor allele frequency $\geq 5 \%$, and were supported by $\geq 10$ reads in at least one passage of the series. Furthermore, we focused our greater analysis on those found in more than one passage and those that substantially rise in frequency. Raw data and consensus sequences will be uploaded during review and before publishing. 
bioRxiv preprint doi: https://doi.org/10.1101/2021.07.16.452629; this version posted July 16, 2021. The copyright holder for this preprint (which was not certified by peer review) is the author/funder, who has granted bioRxiv a license to display the preprint in perpetuity. It is made available under aCC-BY-NC-ND 4.0 International license.

\section{Comparison of SARS-CoV-2 evolution in vitro during passage in Vero and primary human airway cells}

677

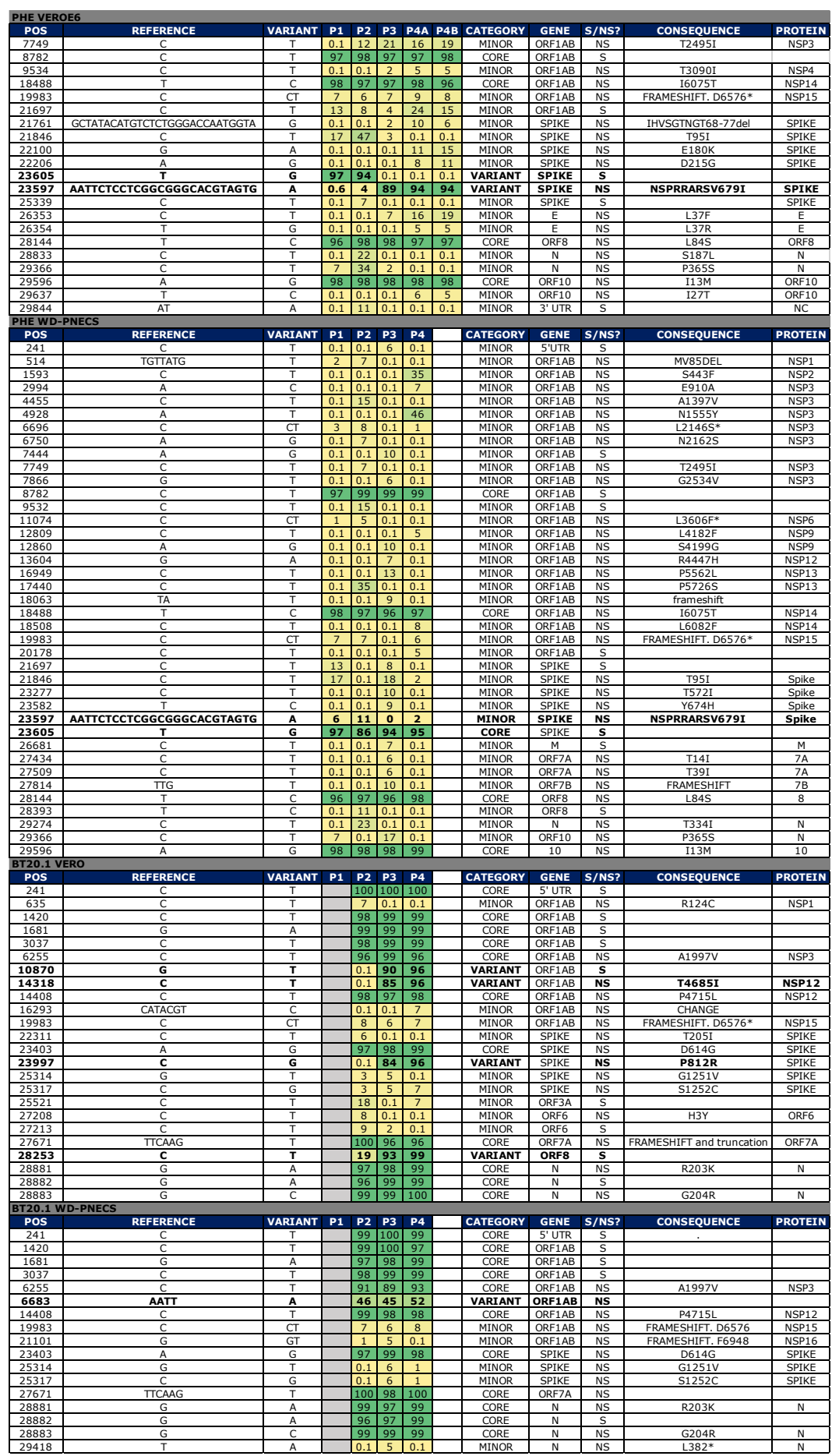


bioRxiv preprint doi: https://doi.org/10.1101/2021.07.16.452629; this version posted July 16, 2021. The copyright holder for this preprint (which was not certified by peer review) is the author/funder, who has granted bioRxiv a license to display the preprint in perpetuity. It is made available under aCC-BY-NC-ND 4.0 International license.

Comparison of SARS-CoV-2 evolution in vitro during passage in Vero and primary human airway cells

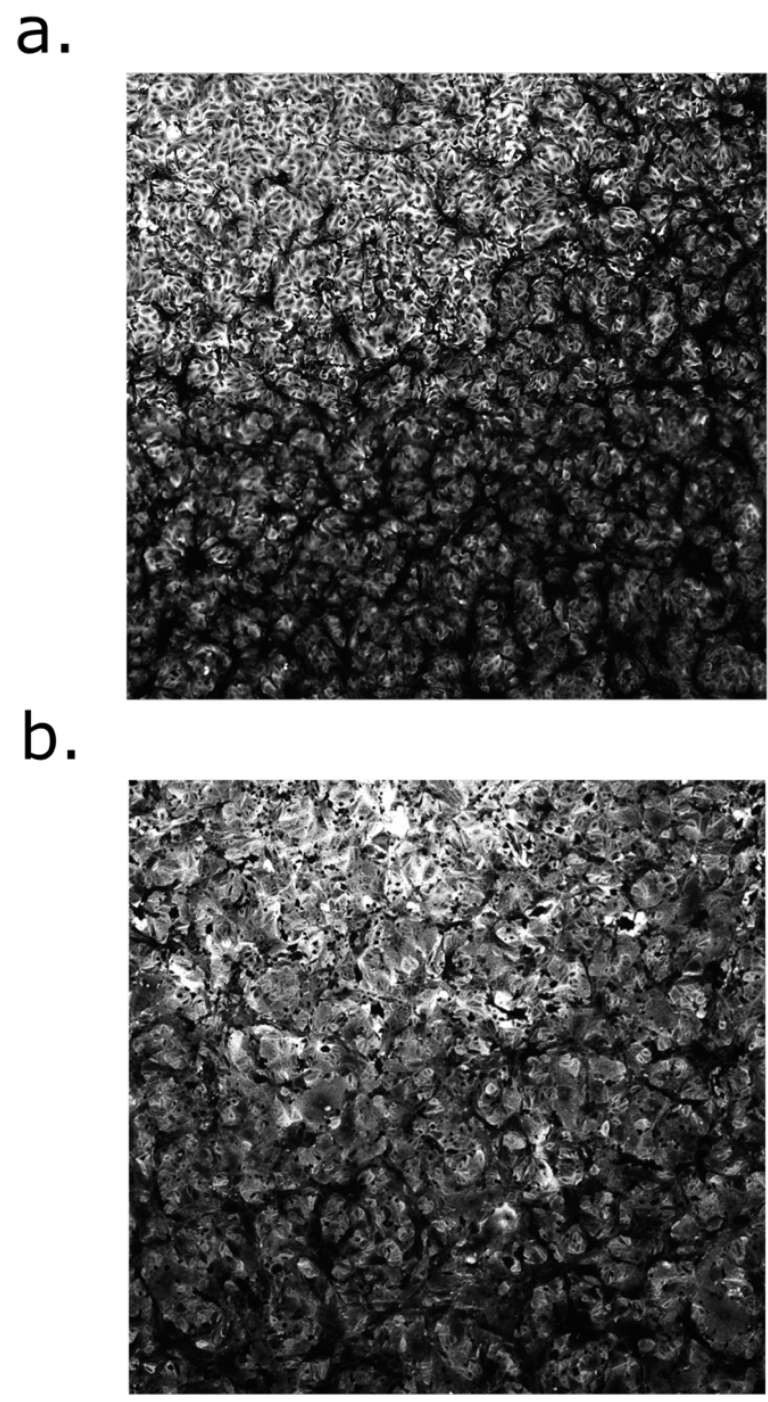

680 
bioRxiv preprint doi: https://doi.org/10.1101/2021.07.16.452629; this version posted July 16, 2021. The copyright holder for this preprint (which was not certified by peer review) is the author/funder, who has granted bioRxiv a license to display the preprint in perpetuity. It is made available under aCC-BY-NC-ND 4.0 International license.

Comparison of SARS-CoV-2 evolution in vitro during passage in Vero and primary human airway cells
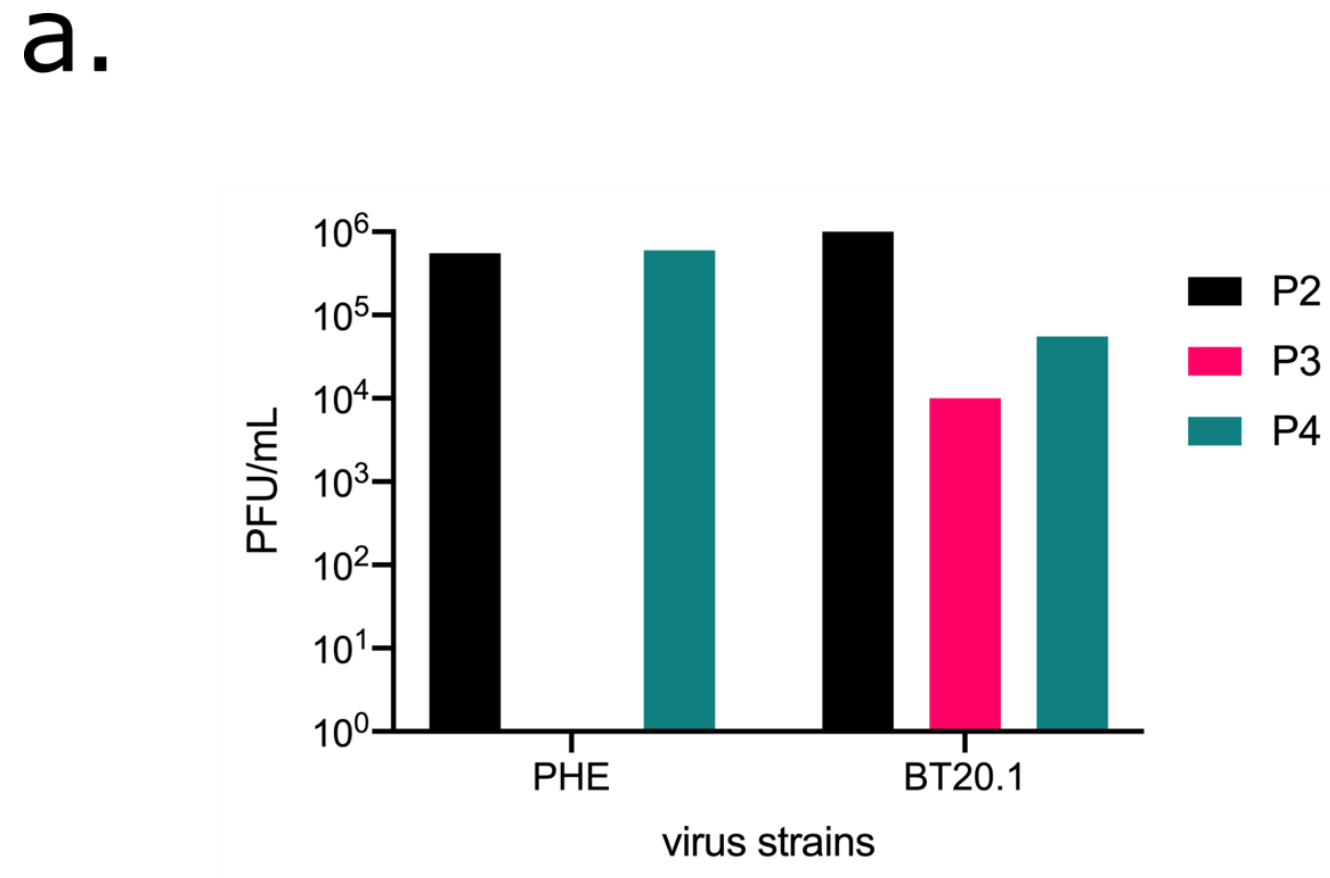
bioRxiv preprint doi: https://doi.org/10.1101/2021.07.16.452629; this version posted July 16, 2021. The copyright holder for this preprint (which was not certified by peer review) is the author/funder, who has granted bioRxiv a license to display the preprint in perpetuity. It is made available under aCC-BY-NC-ND 4.0 International license.

Comparison of SARS-CoV-2 evolution in vitro during passage in Vero and primary human airway cells

a.

b.

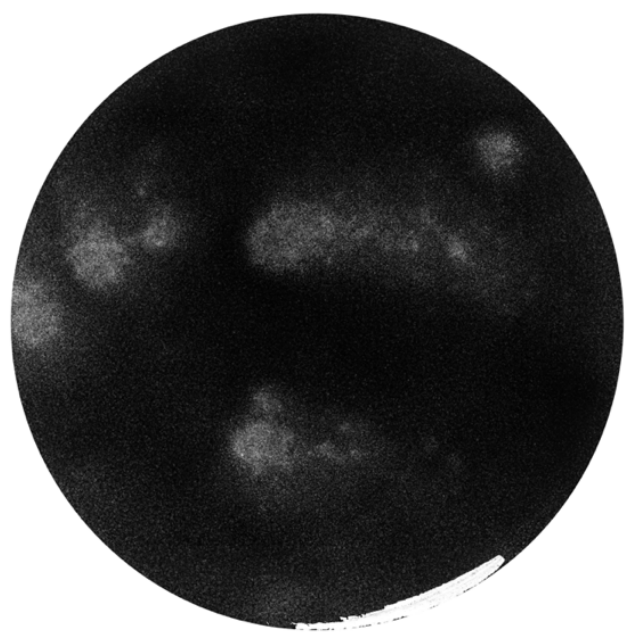

C.
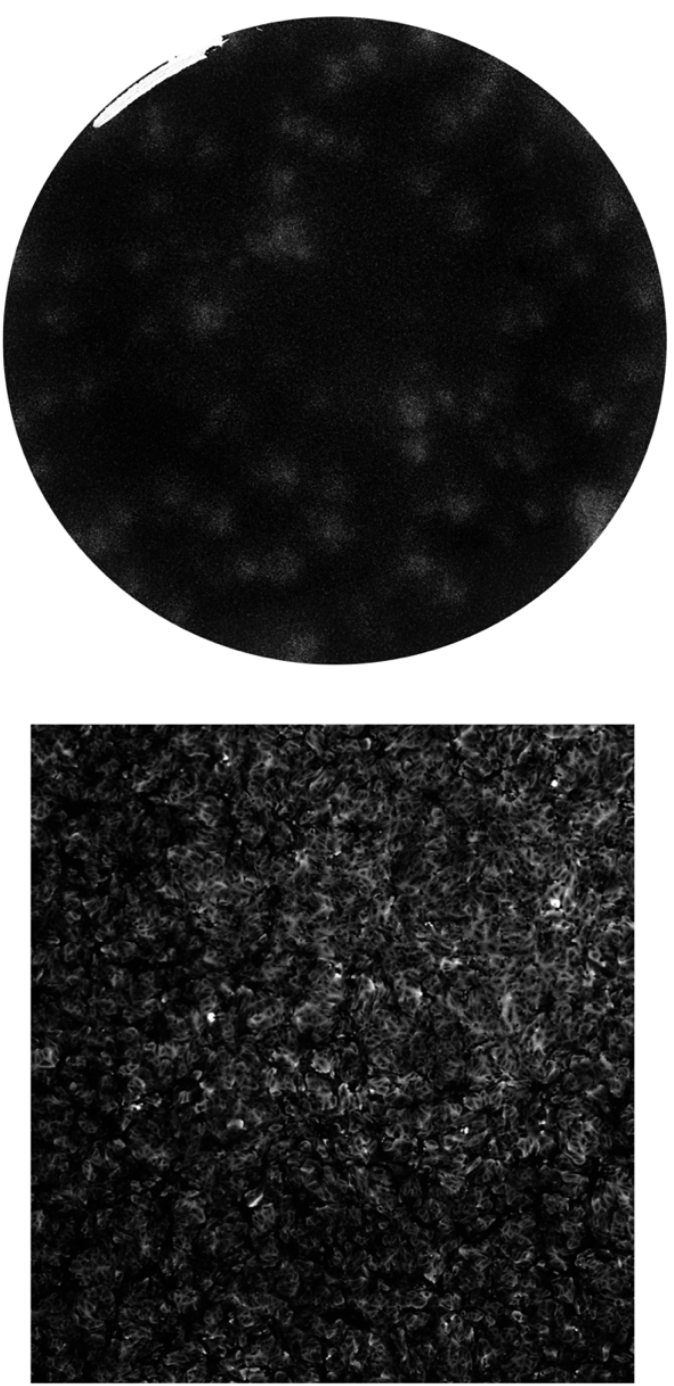
bioRxiv preprint doi: https://doi.org/10.1101/2021.07.16.452629; this version posted July 16, 2021. The copyright holder for this preprint (which was not certified by peer review) is the author/funder, who has granted bioRxiv a license to display the preprint in perpetuity. It is made available under aCC-BY-NC-ND 4.0 International license.

Comparison of SARS-CoV-2 evolution in vitro during passage in Vero and primary human airway cells

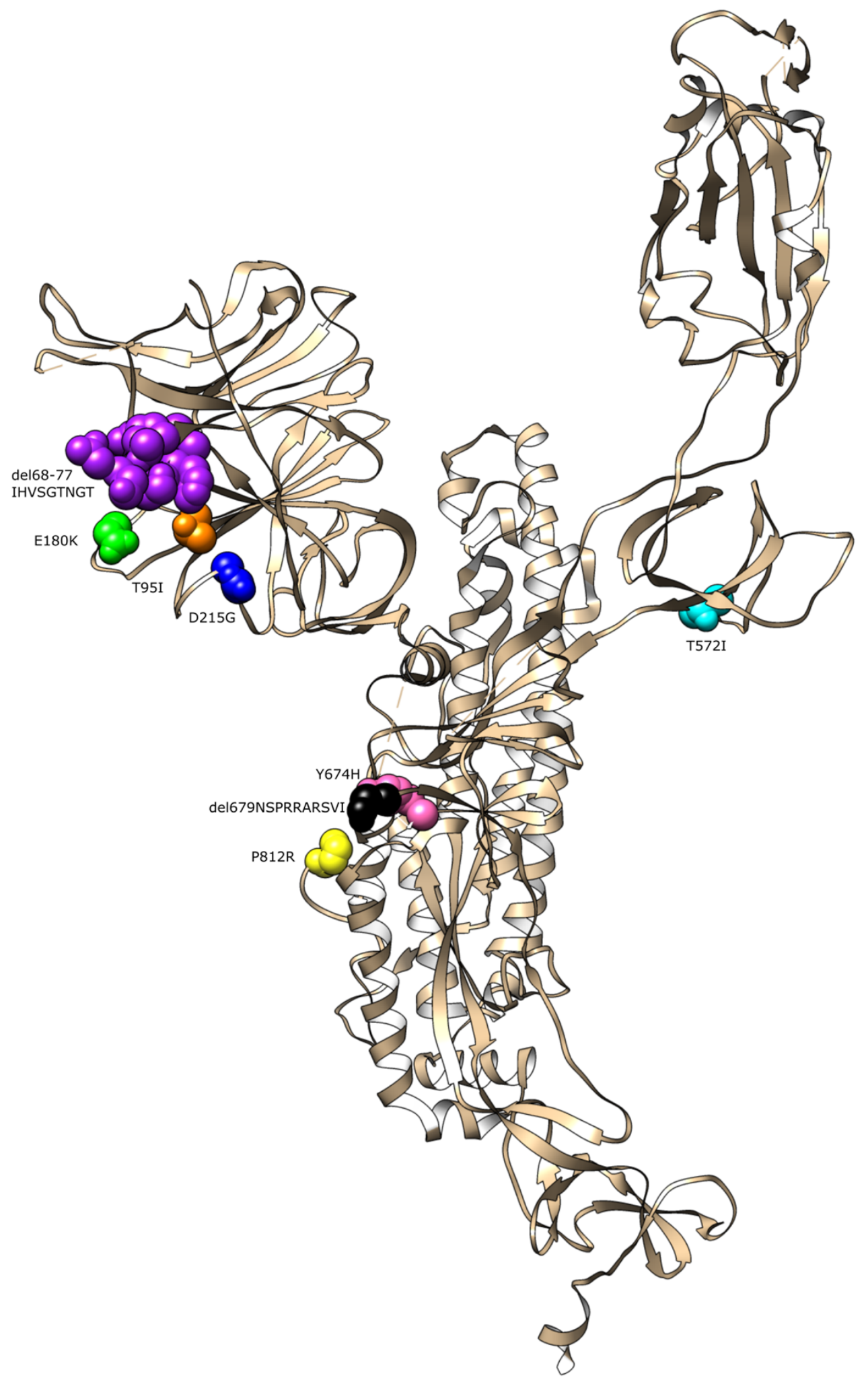


Comparison of SARS-CoV-2 evolution in vitro during passage in Vero and primary human airway cells

695 The authors would like to thank the following individuals and organisations for provision of critical reagents, and technical assistance: Public Health England and Professor Maria Zambon for the original SARSCoV-2 England 02/20 isolate; Belfast Health and Social Care Trust for the original SARS-CoV-2 clinical material from which BT20.1 was derived; Professor Alain Kohl (MRC-University of Glasgow Centre for Virus Research) for the VeroE6 cells; and Dr Suzannah Rihn (MRC-University of Glasgow Centre for Virus Research) for the VeroE6 cells expressing human ACE2 and human TMPRSS2; QUB staff Mervyn McCaigue, Cathy Fenning, David Norwood, Nuala McCann, Paul Crowe and Zoe Hunter for their assistance in establishing and maintaining the QUB SARS-CoV-2 BSL3 facility; and finally, Professor Jose Bengoechea for unwavering support for QUB virology at this critical time. We also wish to thank the QUB Genomics Core Technology Unit for their help with sequencing. Funding from UKRI/NIHR (MC_PC_19057) to UP, KM; PHA HSCNI R\&D Division (COM/5613/20) to UP, KM, LB, CGGB, and GLC; and generous donations from the public to the Queen's University of Belfast Foundation was used for the study. 
bioRxiv preprint doi: https://doi.org/10.1101/2021.07.16.452629; this version posted July 16,2021 . The copyright holder for this preprint (which was not certified by peer review) is the author/funder, who has granted bioRxiv a license to display the preprint in perpetuity. It is made available under aCC-BY-NC-ND 4.0 International license.

Comparison of SARS-CoV-2 evolution in vitro during passage in Vero and primary human airway cells

Boni, M. F., Lemey, P., Jiang, X., Lam, T. T. Y., Perry, B. W., Castoe, T. A., Rambaut, A., \& Robertson, D. L. (2020). Evolutionary origins of the SARS-CoV-2 sarbecovirus lineage responsible for the COVID-19 pandemic. Nature Microbiology, 5(11), 14081417. https://doi.org/10.1038/s41564-020-0771-4

Cevik, M., Bamford, C. G. G., \& Ho, A. (2020). COVID-19 pandemic-a focused review for clinicians. In Clinical Microbiology and Infection (Vol. 26, Issue 7, pp. 842-847). Elsevier B.V. https://doi.org/10.1016/j.cmi.2020.04.023

Chi, X., Yan, R., Zhang, J., Zhang, G., Zhang, Y., Hao, M., Zhang, Z., Fan, P., Dong, Y., Yang, Y., Chen, Z., Guo, Y., Zhang, J., Li, Y., Song, X., Chen, Y., Xia, L., Fu, L., Hou, L., ... Chen, W. (2020). A neutralizing human antibody binds to the N-terminal domain of the Spike protein of SARS-CoV-2. Science, 369(6504), 650-655. https://doi.org/10.1126/SCIENCE.ABC6952

Davidson, A. D., Williamson, M. K., Lewis, S., Shoemark, D., Carroll, M. W., Heesom, K. J., Zambon, M., Ellis, J., Lewis, P. A., Hiscox, J. A., \& Matthews, D. A. (2020). Characterisation of the transcriptome and proteome of SARS-CoV-2 reveals a cell passage induced in-frame deletion of the furin-like cleavage site from the spike glycoprotein. Genome Medicine 2020 12:1, 12(1), 1-15. https://doi.org/10.1186/S13073-020-00763-0

Dieterle, M. E., Haslwanter, D., Bortz, R. H., Wirchnianski, A. S., Lasso, G., Vergnolle, O., Abbasi, S. A., Fels, J. M., Laudermilch, E., Florez, C., Mengotto, A., Kimmel, D., Malonis, R. J., Georgiev, G., Quiroz, J., Barnhill, J., Pirofski, L. anne, Daily, J. P., Dye, J. M., ... Jangra, R. K. (2020). A Replication-Competent Vesicular Stomatitis Virus for Studies of SARS-CoV-2 Spike-Mediated Cell Entry and Its Inhibition. Cell Host and Microbe, 28(3), 486-496.e6. https://doi.org/10.1016/j.chom.2020.06.020

Afgan, E., Baker, D., Batut, B., van den Beek, M., Bouvier, D., Cech, M., Chilton, J., Clements, D., Coraor, N., Gruning, B. A., Guerler, A., Hillman-Jackson, J., Hiltemann, S., Jalili, V., Rasche, H., Soranzo, N., Goecks, J., Taylor, J., Nekrutenko, A., Blankenberg, D. (2018). The Galaxy platform for accessible, reproducible and collaborative biomedical analyses: 2018 update. Nucleic Acids Research, 46(W1), W537-W544. https://doi.org/10.1093/NAR/GKY379

Group, R. collaborative. (2021). Dexamethasone in Hospitalized Patients with Covid-19. New England Journal of Medicine, 384(8), 693-704. https://doi.org/10.1056/nejmoa2021436

Guo-Parke, H., Canning, P., Douglas, I., Villenave, R., Heaney, L. G., Coyle, P. V., Lyons, J. D., Shields, M. D., \& Power, U. F. (2013). Relative Respiratory Syncytial Virus Cytopathogenesis in Upper and Lower Respiratory Tract Epithelium. Https://Doi.Org/10.1164/Rccm.201304-07500C, 188(7), 842-851. https://doi.org/10.1164/RCCM.201304-07500C

Harvey, W. T., Carabelli, A. M., Jackson, B., Gupta, R. K., Thomson, E. C., Harrison, E. M., Ludden, C., Reeve, R., Rambaut, A., COVID-19 Genomics UK (COG-UK) Consortium, Peacock, S. J., \& Robertson, D. L. (2021). SARS-CoV-2 variants, spike mutations and immune escape. Nature Reviews. Microbiology, 19(7), 409-424. https://doi.org/10.1038/s41579-021-00573-0

Hillen, H. S., Kokic, G., Farnung, L., Dienemann, C., Tegunov, D., \& Cramer, P. (2020). Structure of replicating SARS-CoV-2 polymerase. Nature, 584(7819), 154-156. https://doi.org/10.1038/s41586-020-2368-8 
bioRxiv preprint doi: https://doi.org/10.1101/2021.07.16.452629; this version posted July 16,2021 . The copyright holder for this preprint (which was not certified by peer review) is the author/funder, who has granted bioRxiv a license to display the preprint in perpetuity. It is made available under aCC-BY-NC-ND 4.0 International license.

\section{Comparison of SARS-CoV-2 evolution in vitro during passage in Vero and}

\section{primary human airway cells}

Hoffmann, M., Kleine-Weber, H., \& PöhImann, S. (2020). A Multibasic Cleavage Site in the Spike Protein of SARS-CoV-2 Is Essential for Infection of Human Lung Cells. Molecular Cell, 78(4), 779-784.e5. https://doi.org/10.1016/j.molcel.2020.04.022

Holden, B., Quinney, A., Padfield, S., Morton, W., Coles, S., Manley, P., Wensley, A., Hutchinson, C., Lillie, P. J., Duncan, C. J. A., Schmid, M. L., Li, A., Foster, K., Anaraki, S., Dabrera, G., Zambon, M., Hughes, G. J., \& Gent, M. (2020). CoVID-19: public health management of the first two confirmed cases identified in the UK. Epidemiology and Infection, 148. https://doi.org/10.1017/S0950268820001922

Hou, Y. J., Okuda, K., Edwards, C. E., Martinez, D. R., Asakura, T., Dinnon, K. H., Kato, T., Lee, R. E., Yount, B. L., Mascenik, T. M., Chen, G., Olivier, K. N., Ghio, A., Tse, L. V., Leist, S. R., Gralinski, L. E., Schäfer, A., Dang, H., Gilmore, R., ... Baric, R. S. (2020). SARS-CoV-2 Reverse Genetics Reveals a Variable Infection Gradient in the Respiratory Tract. Cell, 182(2), 429-446.e14. https://doi.org/10.1016/j.cell.2020.05.042

Emeny, J.M., \& Morgan, M.J. (1979). Regulation of the interferon system: evidence that Vero cells have a genetic defect in interferon production. The Journal of General Virology, 43(1), 247-252. https://doi.org/10.1099/0022-1317-43-1-247

Johnson, B. A., Xie, X., Bailey, A. L., Kalveram, B., Lokugamage, K. G., Muruato, A., Zou, J., Zhang, X., Juelich, T., Smith, J. K., Zhang, L., Bopp, N., Schindewolf, C., Vu, M., Vanderheiden, A., Winkler, E. S., Swetnam, D., Plante, J. A., Aguilar, P., ... Menachery, V. D. (2021). Loss of furin cleavage site attenuates SARS-CoV-2 pathogenesis. Nature, 591(7849), 293-299. https://doi.org/10.1038/s41586-02103237-4

Klimstra, W. B., Tilston-Lunel, N. L., Nambulli, S., Boslett, J., Mcmillen, C. M., Gilliland, T., Dunn, M. D., Sun, C., Wheeler, S. E., Wells, A., Hartman, A. L., Mcelroy, A. K., Reed, D. S., Rennick, L. J., \& Duprex, W. P. (2020). SARS-CoV-2 growth, furincleavage-site adaptation and neutralization using serum from acutely infected hospitalized COVID-19 patients. Journal of General Virology, 101, 1156-1169. https://doi.org/10.1099/jgv.0.001481

Krammer, F. (2020). SARS-CoV-2 vaccines in development. In Nature (Vol. 586, Issue 7830, pp. 516-527). Nature Research. https://doi.org/10.1038/s41586-020-2798-3

Lamers, M. M., Mykytyn, A. Z., Breugem, T. I., Wang, Y., Wu, D. C., Riesebosch, S., van den Doel, P. B., Schipper, D., Bestebroer, T., Wu, N. C., \& Haagmans, B. L. (2021). Human airway cells prevent sars-cov-2 multibasic cleavage site cell culture adaptation. ELife, 10. https://doi.org/10.7554/ELIFE.66815

Lei, J., Kusov, Y., \& Hilgenfeld, R. (2018). Nsp3 of coronaviruses: Structures and functions of a large multi-domain protein. In Antiviral Research (Vol. 149, pp. 5874). Elsevier B.V. https://doi.org/10.1016/j.antiviral.2017.11.001

Lu, R., Zhao, X., Li, J., Niu, P., Yang, B., Wu, H., Wang, W., Song, H., Huang, B., Zhu, N., Bi, Y., Ma, X., Zhan, F., Wang, L., Hu, T., Zhou, H., Hu, Z., Zhou, W., Zhao, L., ... Tan, W. (2020). Genomic characterisation and epidemiology of 2019 novel coronavirus: implications for virus origins and receptor binding. The Lancet, 395(10224), 565-574. https://doi.org/10.1016/S0140-6736(20)30251-8

Maier, W., Bray, S., Beek, M. van den, Bouvier, D., Coraor, N., Miladi, M., Singh, B., Argila, J. R. De, Baker, D., Roach, N., Gladman, S., Coppens, F., Martin, D. P., Lonie, A., Grüning, B., Pond, S. L. K., \& Nekrutenko, A. (2021). Freely accessible ready to use global infrastructure for SARS-CoV-2 monitoring. BioRxiv, 2021.03.25.437046. https://doi.org/10.1101/2021.03.25.437046 
bioRxiv preprint doi: https://doi.org/10.1101/2021.07.16.452629; this version posted July 16,2021 . The copyright holder for this preprint (which was not certified by peer review) is the author/funder, who has granted bioRxiv a license to display the preprint in perpetuity. It is made available under aCC-BY-NC-ND 4.0 International license.

\section{Comparison of SARS-CoV-2 evolution in vitro during passage in Vero and}

\section{primary human airway cells}

Matsuyama, S., Nao, N., Shirato, K., Kawase, M., Saito, S., Takayama, I., Nagata, N., Sekizuka, T., Katoh, H., Kato, F., Sakata, M., Tahara, M., Kutsuna, S., Ohmagari, N., Kuroda, M., Suzuki, T., Kageyama, T., \& Takeda, M. (2020). Enhanced isolation of SARS-CoV-2 by TMPRSS2-expressing cells. Proceedings of the National Academy of Sciences, 117(13), 7001-7003. https://doi.org/10.1073/PNAS.2002589117

Nemudryi, A., Nemudraia, A., Wiegand, T., Nichols, J., Snyder, D. T., Hedges, J. F., Cicha, C., Lee, H., Vanderwood, K. K., Bimczok, D., Jutila, M. A., \& Wiedenheft, B. (2021). SARS-CoV-2 genomic surveillance identifies naturally occurring truncation of ORF7a that limits immune suppression. Cell Reports, 35(9), 109197. https://doi.org/10.1016/j.celrep.2021.109197

Ogando, N. S., Dalebout, T. J., Zevenhoven-Dobbe, J. C., Limpens, R. W. A. L., van der Meer, Y., Caly, L., Druce, J., de Vries, J. J. C., Kikkert, M., Barcena, M., Sidorov, I., \& Snijder, E. J. (2020). SARS-coronavirus-2 replication in Vero E6 cells: Replication kinetics, rapid adaptation and cytopathology. Journal of General Virology, 101(9), 925-940. https://doi.org/10.1099/jgv.0.001453

Peacock, T. P., Goldhill, D. H., Zhou, J., Baillon, L., Frise, R., Swann, O. C., Kugathasan, R., Penn, R., Brown, J. C., Sanchez-David, R. Y., Braga, L., Williamson, M. K., Hassard, J. A., Staller, E., Hanley, B., Osborn, M., Giacca, M., Davidson, A. D., Matthews, D. A., \& Barclay, W. S. (2021). The furin cleavage site in the SARS-CoV2 spike protein is required for transmission in ferrets. Nature Microbiology, 1-11. https://doi.org/10.1038/s41564-021-00908-w

Pohl, M. O., Busnadiego, I., Kufner, V., Glas, I., Karakus, U., Schmutz, S., Zaheri, M., Abela, I., Trkola, A., Huber, M., Stertz, S., \& Hale, B. G. (2021). SARS-CoV-2 variants reveal features critical for replication in primary human cells. PLOS Biology, 19(3), e3001006. https://doi.org/10.1371/journal.pbio.3001006

Ramirez, S., Fernandez-Antunez, C., Galli, A., Underwood, A., Pham, L. V., Ryberg, L. A., Feng, S., Pedersen, M. S., Mikkelsen, L. S., Belouzard, S., Dubuisson, J., Sølund, C., Weis, N., Gottwein, J. M., Fahnøe, U., \& Bukh, J. (2021). Overcoming culture restriction for SARS-CoV-2 in human cells facilitates the screening of compounds inhibiting viral replication. Antimicrobial Agents and Chemotherapy, 65(7). https://doi.org/10.1128/aac.00097-21

Rihn, S. J., Merits, A., Bakshi, S., Turnbull, M. L., Wickenhagen, A., Alexander, A. J. T., Baillie, C., Brennan, B., Brown, F., Brunker, K., Bryden, S. R., Burness, K. A., Carmichael, S., Cole, S. J., Cowton, V. M., Davies, P., Davis, C., Lorenzo, G. De, Donald, C. L., ... Mahalingam, S. (2021). A plasmid DNA-launched SARS-CoV-2 reverse genetics system and coronavirus toolkit for COVID-19 research. PLOS Biology, 19(2), e3001091. https://doi.org/10.1371/JOURNAL.PBIO.3001091

Shang, J., Ye, G., Shi, K., Wan, Y., Luo, C., Aihara, H., Geng, Q., Auerbach, A., \& Li, F. (2020). Structural basis of receptor recognition by SARS-CoV-2. Nature, 581(7807), 221-224. https://doi.org/10.1038/s41586-020-2179-y

Tyson, J. R., James, P., Stoddart, D., Sparks, N., Wickenhagen, A., Hall, G., Choi, J. H., Lapointe, H., Kamelian, K., Smith, A. D., Prystajecky, N., Goodfellow, I., Wilson, S. J., Harrigan, R., Snutch, T. P., Loman, N. J., \& Quick, J. (2020). Improvements to the ARTIC multiplex PCR method for SARS-CoV-2 genome sequencing using nanopore. BioRxiv, 3, 2020.09.04.283077. https://doi.org/10.1101/2020.09.04.283077

Villenave, R., Thavagnanam, S., Sarlang, S., Parker, J., Douglas, I., Skibinski, G., Heaney, L. G., McKaigue, J. P., Coyle, P. V, Shields, M. D., \& Power, U. F. (2012). In vitro modeling of respiratory syncytial virus infection of pediatric bronchial 
bioRxiv preprint doi: https://doi.org/10.1101/2021.07.16.452629; this version posted July 16, 2021. The copyright holder for this preprint (which was not certified by peer review) is the author/funder, who has granted bioRxiv a license to display the preprint in perpetuity. It is made available under aCC-BY-NC-ND 4.0 International license.

Comparison of SARS-CoV-2 evolution in vitro during passage in Vero and primary human airway cells

epithelium, the primary target of infection in vivo. Proceedings of the National Academy of Sciences of the United States of America, 1-6. https://doi.org/10.1073/pnas.1110203109

Wang, Z., Yang, B., Li, Q., Wen, L., \& Zhang, R. (2020). Clinical Features of 69 Cases with Coronavirus Disease 2019 in Wuhan, China. Clinical Infectious Diseases. https://doi.org/10.1093/cid/ciaa272

Wu, F., Zhao, S., Yu, B., Chen, Y.-M., Wang, W., Song, Z.-G., Hu, Y., Tao, Z.-W., Tian, J.-H., Pei, Y.-Y., Yuan, M.-L., Zhang, Y.-L., Dai, F.-H., Liu, Y., Wang, Q.-M., Zheng, J.-J., Xu, L., Holmes, E. C., \& Zhang, Y.-Z. (2020). A new coronavirus associated with human respiratory disease in China. Nature, 579(7798), 265-269. https://doi.org/10.1038/s41586-020-2008-3 